\title{
Holocene tectonic uplift on the Hua-tung coast, eastern Taiwan
}

\author{
Meng-Long Hsieh ${ }^{\mathrm{a}, *}$, Ping-Mei Liew ${ }^{\mathrm{a}}$, Ming-Yang Hsu ${ }^{\mathrm{b}}$ \\ a Department of Geosciences, National Taiwan University, No. 1, Sec. 4, Roosevelt Road, Taipei 106, Taiwan, ROC \\ ${ }^{\mathrm{b}}$ Department of Nature Science Education, Taipei Municipal Teacher's College, Taiwan, ROC
}

\begin{abstract}
We used radiometric dates from 19 sites to determine the Holocene uplift rates of the 140-km-long Hua-tung coast in eastern Taiwan. These rates ensure that the formation of major marine terraces on the coast, several tens of meters in height, is related to the deglacial relative sea-level cycle, with which the uplift rates were further constrained by the elevations of the marine-terrace elements. Uplift rates are less than $4 \mathrm{~mm} / \mathrm{yr}$ in the northernmost $30 \mathrm{~km}$-long coast, and are $4-7 \mathrm{~mm} / \mathrm{yr}$ in the adjacent $30-\mathrm{km}-\mathrm{long}$ coast. The rest of the coast is generally uplifted $7-9 \mathrm{~mm} / \mathrm{yr}$, with local troughs $(<4 \mathrm{~mm} / \mathrm{yr}$ in uplift rate) occurring around $90-95$ and $105-$ $110 \mathrm{~km}$ south of the north end of the surveys. The crest of the uplift, with rates greater than $10 \mathrm{~mm} / \mathrm{yr}$, is located within the southernmost $10 \mathrm{~km}$. Seaward tilting is also suggested in much of the middle and southern part of the coast where wide $(>700 \mathrm{~m})$ and high $(>40 \mathrm{~m})$ mudstone platforms are observed to slope below the sea level. These changes in uplift rate or style are all accommodated on the surface by warping. Most of them are irrelevant to the known bedrock structures, suggesting a change in uplift style, and perhaps also mechanics, of the coast during the Holocene.
\end{abstract}

(C) 2003 Elsevier Ltd and INQUA. All rights reserved.

\section{Introduction}

Uplift rates in mountain ranges constitute one of the most basic quantifiable aspects of orogenesis. For time spans of thousands to tens of thousands of years, uplift rates inside the mountains must be inferred indirectly by the rates of channel incision into bedrock (e.g., Burbank et al., 1996). In coastal areas, these uplift rates may be more straightforward to document, once the relative sea-level histories (a net result of uplifts and eustatic sealevel movements) are known (e.g., Lajoie, 1986). These short-term uplift rates, of course, may not be representative of uplifts over time spans of entire orogenies. They, however, link the long-term uplift rates derived from geological evidence to the recent ones, and provide insights into the ongoing orogenic processes and their potential seismic activities in the future. Herein we present geomorphic observations that constrain Holocene uplift in the coast bordering the Coastal Range of eastern Taiwan, one of the youngest elements of the Taiwan orogenic belt.

The mountain ranges of Taiwan result from collision between the Luzon volcanic arc of the Philippine Sea

*Corresponding author. Tel.: +886-2-23630231; fax: +886-223636095.

E-mail address: hsiehml@pchome.com.tw (M.-L. Hsieh). plate and the Chinese continental margin of the Eurasian plate, starting 4-5 million years ago (e.g., Biq, 1973; Ho, 1986; Teng, 1990) (Fig. 1). The 140-mlong, up-to-1600-m-high Coastal Range is the easternmost. It is separated from the 3000-m-high Central Range to the west by the Longitudinal Valley, the collision suture filled by thick sediments (Fig. 1). The emergence of the Coastal Range is tectonically significant. The range is small compared with the Central Range, and is restricted merely in the central part of eastern Taiwan. The Coastal Range is the only place in Taiwan that exposes rock formations pertaining to the Philippine Sea plate (Fig. 1). To the west, the Central Range consists of mid-crustal metamorphic rocks of the deformed Chinese continental margin. As the orogenic process propagated to the west, the degree of rock deformation decreased and the strata incorporated into the mountains become younger toward the Western Foothills (Fig. 1). The Coastal Range, composed of non-metamorphic deposits, is not part of this sequence. The range, also, is the only place in eastern Taiwan that is fringed with multiple steps of marine terraces.

Although small, the Coastal Range is known for its rapid tectonic uplift. The uplift rate since the MiddleLate Pleistocene was estimated at least $7.5 \mathrm{~mm} / \mathrm{yr}$ (Lundberg and Dorsey, 1990), or $12 \mathrm{~mm} / \mathrm{yr}$ (Chen et al., 1991) from stratigraphic evidence. Along the 

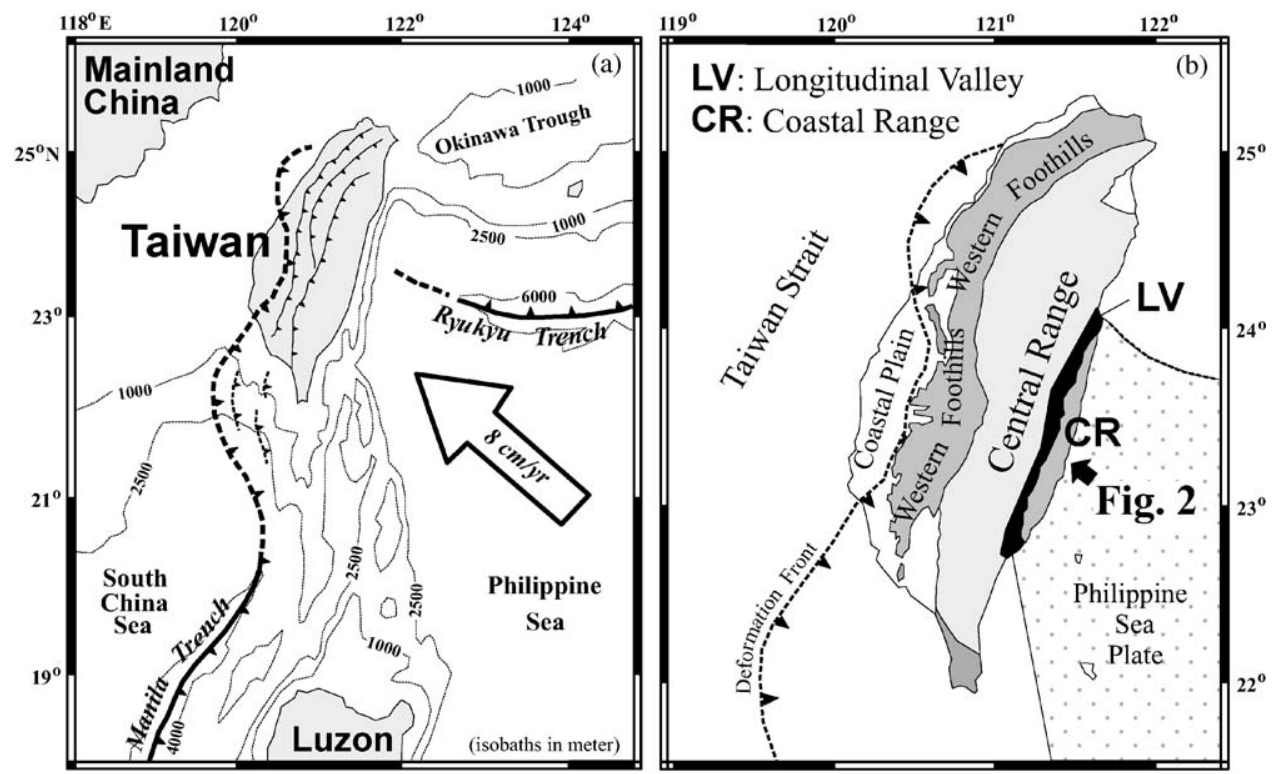

Fig. 1. (a) Tectonic setting of Taiwan. Open arrow with rate shows the current movement of the Philippine Sea plate relative to the Chinese continental margin based on GPS data (Yu et al., 1997). (b) Morpho-tectonic framework of Taiwan and the location of the Coastal Range (CR) (summarized from Ho, 1986).

coast (i.e. the coast between Hua-lien and Tai-tung, or the Hua-tung coast; Fig. 2), uplift rates of at least several millimeters per year are constrained by more than 120 radiometric dates, mostly middle to late Holocene (Hsu et al., 1973; Peng et al., 1977; Lin, 1989; Chen et al., 1991; Liew et al., 1993; Vita-Finzi and Lin, 1998; Yamaguchi and Ota, 2001, for review see Hsieh et al., 2001). Geodetic surveys further showed that much of the coast is currently uplifting at rates on the order of centimeters per year (Chen, 1984; Liu and Yu, 1990).

The uplift of the Hua-tung coast is not uniform along the coast, as shown by the geodetic data (Chen, 1984; Liu and Yu, 1990). Different investigators, however, had different interpretations or hypotheses of the coast's differential uplift pattern. The apparently higher and wider terraces around Chang-pin, Cheng-kung and Tulan (Fig. 2) were believed to reflect the maximum uplifts (Hsu, 1954; Biq, 1972; Shih and Teng, 1977; Hsu, 1988). Lai (1987) correlated these terraces in a different manner and argued that the middle part of the coast should have uplifted uniformly. Liew et al. (1990) suggested that the northern part of the coast, with terraces generally lower and narrower, was raised more slowly than the middle and southern parts of the coast. Using known faults on the geological maps as boundaries, Lin (1994), VitaFinzi and Lin (1998) separated the coast into several neotectonic units. Each presumably had a distinct uplift pattern and history. However, all these interpretations were made based on insufficient radiometric dates and when the detailed stratigraphy underlying the terraces had not been made clear. The inferred uplift patterns, also, are incompatible with the patterns revealed by the geodetic data in some respects (Vita-Finzi and Lin, 1998; Hsieh et al., 2001).

In this paper, we re-examine the Holocene tectonic uplift of the coast (we focused the time scale on the Holocene, and will present the coast's shorter-term uplift, which probably involved coseismic components, elsewhere). We first integrate all the available radiometric dates older than $3 \mathrm{ka}$, including those published and our new data, to deduce uplift rates at multiple sites. For this purpose, we apply the newly developed postglacial sea-level curve in Taiwan (Chen and Liu, 1996, 2000) and refer the coast's late-glacial sea-level datum to the record in the Sunda Shelf, Indonesia (Hanebuth et al., 2000). We assume that the uplift rates thus derived are representative over the time scale being concerned.

Secondly, we review the morphology and sequences of the terraces along the coast. With their great diversities, the genesis (and preservation) of these terraces may have been controlled by the factors other than the relative sea-level movement, such as climate-related along-shore sediment transport and storm-wave activity. This complexity had made the correlation of these terraces difficult and subjective: the reason why different investigators had different interpretations of the coast's uplift pattern. We appreciate this complexity and explore the origins of these terraces by considering the uplift rates deduced from the radiometric dates. We extract tectonic signals from the topographic elements of these terraces, so that the uplift rates deduced from the dates at separated sites can be interpolated, and uplift boundaries be defined, with more confidence. Finally, 


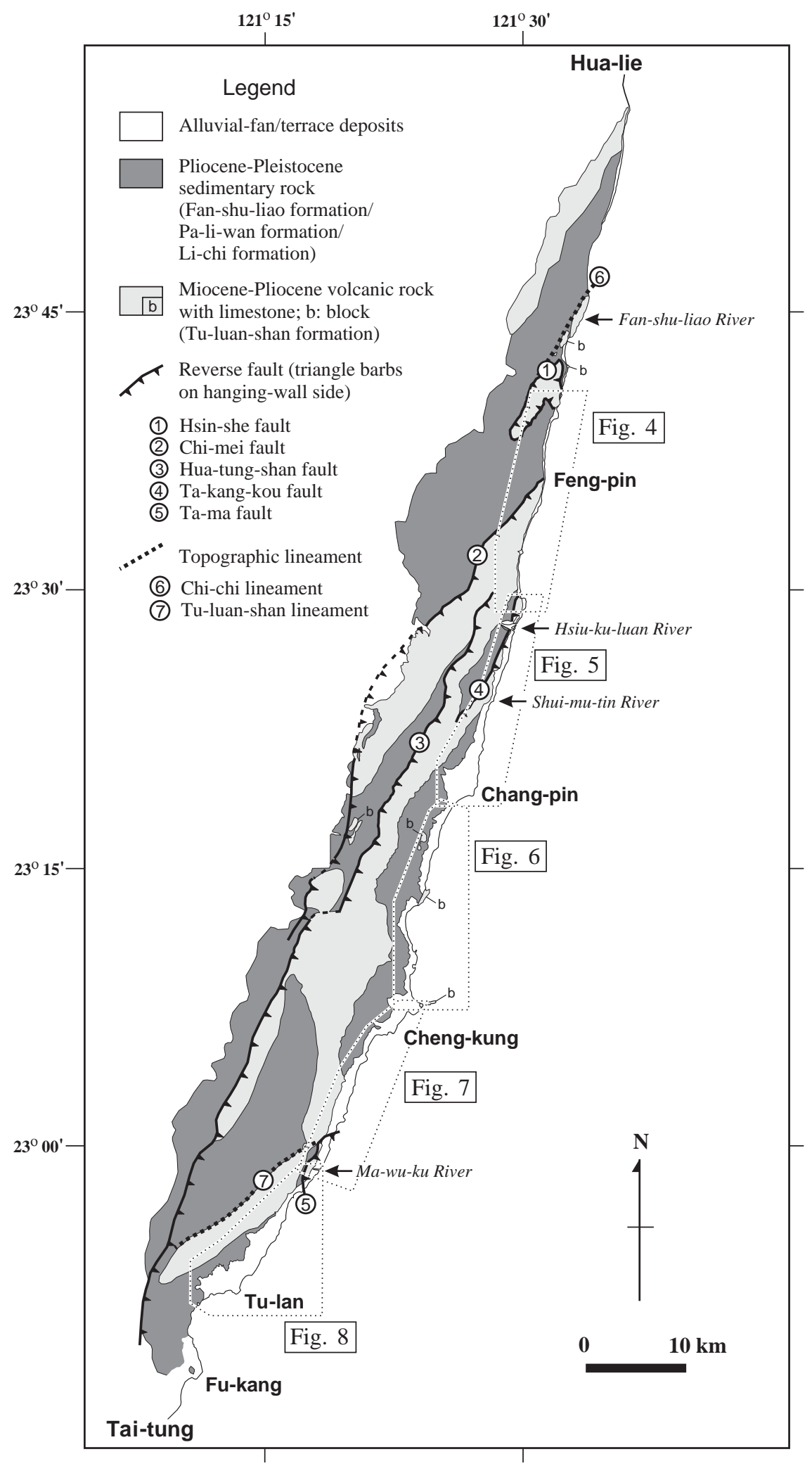

Fig. 2. Geological map of the Coastal Range (summarized from Chen, 1988; Wang et al., 1992; Lo et al., 1993; Chen and Wang, 1997). For location see Fig. 1. The Chi-chi and Tu-luan-shan lineaments follow the Chi-chi and Tu-luan-shan faults of Hsu (1956). The mouths of four major antecedentor consequent-type rivers that traverse major reverse faults or hard volcanic rock are also pointed. 
we discuss the tectonic implications of our data by comparing them with the long-term uplift of the range revealed by bedrock structures.

\section{Bedrock formations and structures}

The Coastal Range mainly consists of two types of rock: the island-arc-related Miocene to early Pliocene volcanic rock (lava, pyroclastic breccia, tuff and epiclastic sandstone) (e.g., Hsu, 1956; Yen, 1968; Song and Lo, 1988), and the Pliocene to early Pleistocene sedimentary rock (mudstone, sandstone and conglomerate) deposited in deep-seated fore-arc/inter-arc basins (e.g., Hsu, 1956; Teng and Lo, 1985; Chen, 1988) (Fig. 1). Overlying the volcanic rock, lenticular limestone masses occur at some places. These document the activity of shallow marine biota after the construction of the arc volcanoes and before the subsidence of the basins (e.g., Huang et al., 1988; Chen, 1988). The volcanic rock also occurs as blocks within the sedimentary sequences (Fig. 2). These blocks, varying from few meters to more than $1 \mathrm{~km}$ in length, were probably emplaced by rock falls or slides from the volcanoes around the basins (Song et al., 1994). In addition to these rocks, the collisional mélange, consisting of sheared mudstone with sandstone and ophiolitic blocks, is exposed on the eastern and the southernmost part of the range.

Both the volcanic and sedimentary rocks are folded or thrust-faulted during their uplift. The structures are parallel or sub-parallel to the coast. Only a few major faults were mapped across the coast: from north to south, they are the Hsin-she fault (Chen and Wang, 1997), the Chi-mei fault, the Ta-kang-kou fault, and the Ta-ma fault (Hsu, 1956; Wang et al., 1992; Lo et al., 1993) (Fig. 2). These faults all dip to the east, along which the volcanic rock on the hanging-wall side thrusts over the sedimentary rock on the footwall side. The Chimei, Ta-kang-kou, and Ta-ma faults are high-angle faults $\left(>60^{\circ}\right)$. The Chi-mei fault, the only fault extending across the entire range, is believed to be the most important fault system, and may still be active, as suggested by Chen et al. (1991). The Hsin-she fault is a low-angle thrust fault. Chen and Wang (1997) suspected that the volcanic rock on the hanging-wall side of this fault may have been a giant sedimentary block, and the fault, therefore, may not be a major one.

In addition to these faults, Hsu (1956) had mapped two prominent lineaments on the range as faults: the Chi-chi fault in the north and the Tu-luan-shan fault in the south (merging to the north with the Ta-ma fault) (Fig. 2). With these two "faults", the major fault system cutting the Coastal Range was believed to be imbricateand en-echelon-arranged, accommodating the oblique collision (and progressive accretion) between the Luzon volcanic arc and the Chinese continental margin (Hsu, 1956; Lee et al., 1991; Lin, 1994; Vita-Finzi and Lin, 1998). Lin (1994) and Vita-Finzi and Lin (1998) also used the two "faults" as the boundaries of their neotectonic units. Advanced surveys by Lo et al. (1993), Chen and Wang (1997), however, do not favor the fault origin of these two lineaments. Instead, they probably reflect the lithological contrast between the volcanic rock and the sedimentary rock (Fig. 2).

\section{Marine-terrace sequences and radiometric dates}

\subsection{General picture}

Fig. 3 summarizes the morphological elements of the marine terraces along the coast. These terraces have widths of up to $3 \mathrm{kms}$. They are associated landward with alluvial fans and have apparently great heights $(>100 \mathrm{~m})$ in many places, especially around Changpin and Tulan. The terraces consist of marine and fluvial sediments of various types and thicknesses (for descriptions see Hsieh (1990)), and are commonly underlain by bedrock platforms or benches. Being deeply buried by alluvium, the true shoreline angles of these platforms that indicate the positions of the former shorelines are rarely exposed. We observed them mainly from the channel-cut profiles along some major rivers.

Bedrock lithology apparently has a significant control on the morphology of the coast and the terraces. The much more resistant volcanic rock commonly forms rocky coast and headlands. The terraces cut into this type of rock also are narrower and lower than their adjacent terraces underlain by sedimentary rock (mostly mudstone) (Fig. 3). In some places, the terraces underlain by sedimentary rock end landward with slopes composed of volcanic rock or limestone (Fig. 3). In these places, the extent of the sedimentary rock appears to have controlled the widths of these terraces.

Among the wide terraces underlain by sedimentary rock ( $>500 \mathrm{~m}$ in width; developed south of Chang-pin), two types can be differentiated. Type I terraces are those truncated seaward by precipitous sea cliffs or terrace risers, and have relatively thin (a few meters) marinesediment covers. Type II terraces consist of thick covers of marine sequences and bedrock platforms that extend continuously underneath the modern coast. The average gradients of the bedrock platforms underlying the two types of terraces are all greater than $1^{\circ}$ or even $2^{\circ}$, assuming that they are equivalent to the surface gradients of the terraces where alluvial fans are absent. The modern coast, bordering the Type I terraces, is very erosive. In many places, the retreat of the sea cliffs has been estimated on the order of meters per year in the past decades (Hsu et al., 1999; Shen, 2000), even though the coast is currently uplifting at very high rates. 


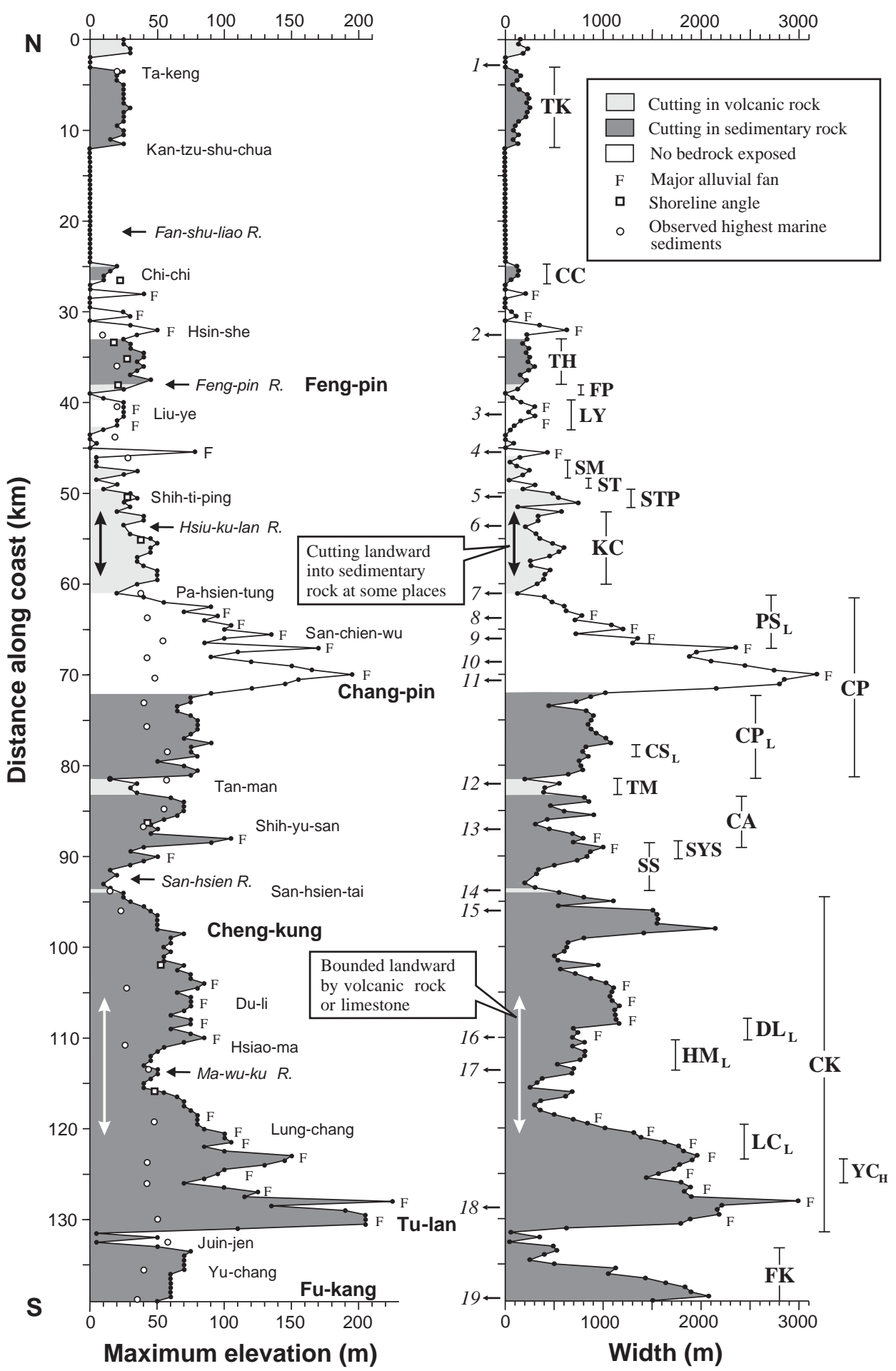

Fig. 3. Summary of morphology of marine terraces in the Hua-tung Coast (0 km: Hua-lien River mouth; 139 km: Fu-kang Harbour) from 1-to-5000scale topographic maps (contour interval: $5 \mathrm{~m}$ ); survey spacing $0.5 \mathrm{~km}$ along the coast (dots). Italic numerals are sites of dates shown in Table 1 . Locations of major terraces labeled in this study are also shown.

Next, we review, from north to south, the morphology and available chronology ( $>3 \mathrm{ka}$ ) of the marine terraces along the coast. The terraces commonly consist of multiple steps separated by minor $(<5 \mathrm{~m}$ high) and discontinuous terrace risers. For the time scale being concerned, we scale down these terraces according to 1-5000-scale topographic maps with contour intervals of $5 \mathrm{~m}$. Terraces (hereafter major terraces) that can be resolved from these maps must have widths of at least several tens of meters, and terrace risers no smaller than $5 \mathrm{~m}$ in height. We label the terraces for the convenience of description (i.e., no chronological connotation). Only 
terraces that are (or appear to be) physically connected (i.e. only dissected by channels) are denoted by the same labels. All the dates derived by the radiocarbon method are calibrated to calendar ages following Stuiver and Reimer (1993). These dates are presented as calibrated age ranges incorporating one standard deviation. In some cases, ages of deposits are expressed as approximated age ranges where more than one date from the deposits is available. Heights of objects are relative to mean sea level (tidal range $<1 \mathrm{~m}$ ) and are denoted as single values where they were surveyed by hand leveling or total station, or as 5-m-ranges where they were determined from 1 to 5000 -scale topographic maps.

\subsection{Hua-lien River to Hsin-she}

This part of the coast is generally narrow and consists of steep, conglomeratic or volcanic sea cliffs in many places. Relatively wide terraces $(<300 \mathrm{~m}$ wide) occur only between the Hua-lien River and Kan-tzu-shu-chua (labeled TK), in a bay around Chi-chi (labeled CC) (Fig. 3), and as several abandoned fan deltas from Chichi to Hsin-she; the Hsin-she terrace in the south is the largest (Fig. 4).

The TK terrace has an apparent shoreline angle 20$25 \mathrm{~m}$ in elevation. It is underlain mainly by a mudstone or conglomeratic platform with covers of beach/fluvial sediments of some meters in thickness. North of Takeng the coast is covered by coarse, volcanic deposits of landslide/debris-flow origin. These coarse materials are locally onlapped by beach gravel and dune sand as high as $20 \mathrm{~m}$ in elevation. Fossil algae (17.5 $\mathrm{m}$ in elevation) on a boulder, probably an erosional remnant of the debrisflow deposits, are dated $7154-7208 \mathrm{cal}$. yr BP by Hsu et al. (1998) (Table 1). The CC terrace, less than $10 \mathrm{~m}$ in height, is composed mainly of fluvial sediments overlying a mudstone platform. Above this terrace, two mudstone-based terrace remnants are preserved; they have shoreline angles $20-25 \mathrm{~m}$ in elevation.

The Hsin-she terrace consists of coarse, submarine debris-flow deposits in the lower part, fluvial channel sequences in the upper part, and a transitional zone in between (Fig. 4). The debris-flow deposits are dated 3.7$4.2 \mathrm{ka}$ (Fig. 4, profile a; Table 1, Location 2). The two youngest dates (3.7-3.9 ka) are derived at $8-9 \mathrm{~m}$ above sea level, or $1-2 \mathrm{~m}$ below the well-defined fluvial sediments.

\subsection{Hsin-she to Shih-ti-ping}

A major terrace (labeled $\mathrm{TH}$ ) underlain by a mudstone platform is continuously developed from Hsin-she to the mouth of the Feng-pin River. It is generally $200 \mathrm{~m}$ in width and merges to the north with the Hsin-she terrace. The terrace is lower north of Tunghsing, where it has an apparent shoreline angle of
20-25 $\mathrm{m}$ in elevation (Fig. 4, profile b). To the south, the terrace rises to as high as $35-40 \mathrm{~m}$ in elevation (Fig. 4, profile c). These lower and higher terraces are bounded by an indistinct slope striking normal to the shore (Fig. 4). This boundary is exposed on the sea cliff as a vertical, erosional surface separating the mudstone bedrock to the south and fluvial sediments to the north.

A major terrace (labeled FP) underlain by volcanic rock is developed south of the Feng-pin River (and the Chi-mei fault). It has a shoreline angle at $21-22 \mathrm{~m}$ in elevation, as exposed along the river. Here, the volcanic rock and its overlying fluvial/beach gravel are offset $1-2 \mathrm{~m}$ vertically by a reverse fault dipping $80^{\circ}$ to the east (Fig. 4, profile d). Within this fluvial/beach gravel, abundant pottery fragments are found. They pertain to the Neolithic culture emerging after $3.5 \mathrm{ka}$ (Liu and Yen, 2000). The fault is sub-parallel to the coast, and was believed to be a branch of the Chi-mei fault system (Chen et al., 1991). The Chi-mei fault, however, does not appear to displace or deform the river terraces developed along the southern bank of the Feng-pin River.

The FP terrace does not extend for more than $1 \mathrm{~km}$ to the south. Around Liu-ye, another major terrace (labeled LY) appears (Fig. 4). The LY terrace has a similar elevation with the FP terrace, and consists of submarine debris-flow deposits, which are truncated on the top by beach/fluvial gravel. The debris-flow deposits are dated 9049-9452 cal. yr BP by Lai (1987). To the south, the coast consists of narrow benches $(<10 \mathrm{~m}$ in elevation) eroded to volcanic rock. Remnants of beach gravel are exposed as high as $19 \mathrm{~m}$ above sea level on the adjacent sea cliffs. Farther south, the coast around Ta-wan develops a fan delta, whose basal submarine debris-flow deposits are dated 12174-12795 cal. yr BP (Table 1; Location 4).

South from Ta-wan, the coast develops a distinct volcanic platform (labeled SM) up to $150 \mathrm{~m}$ in width and no more than $4 \mathrm{~m}$ in elevation (Fig. 4). Remnants of higher platforms $(<20 \mathrm{~m}$ in elevation), sea stacks and caves also occur. The SM platform extends for about $2 \mathrm{~km}$ along the coast. The following $1-\mathrm{km}$-long coast (where the Ta-kang-kou fault crosses) develops a terrace (labeled ST) up to $300 \mathrm{~m}$ wide and no more than $15 \mathrm{~m}$ high above sea level (Fig. 4). Unlike the SM terrace, which lacks sediment cover, the ST terrace consists of fluvial and beach deposits of unknown thicknesses.

Farther south, a more than $500 \mathrm{~m}$-wide major terrace (labeled STP), underlain by volcanic rock, is developed around Shih-ti-ping (Fig. 4, profile g). It has a shoreline angle $25-30 \mathrm{~m}$ in elevation, and is composed of several steps of bedrock benches, on which fossil corals and marine shells lie. These marine fossils have been dated by Lai (1987), Lin (1989), Vita-Finzi and Lin (1998), and Yamaguchi and Ota (2001). The oldest age, $5100 \pm 600 \mathrm{yr}$ BP by the U/Th method, was dated at an elevation $22 \mathrm{~m}$ above sea level (Lin, 1989). 


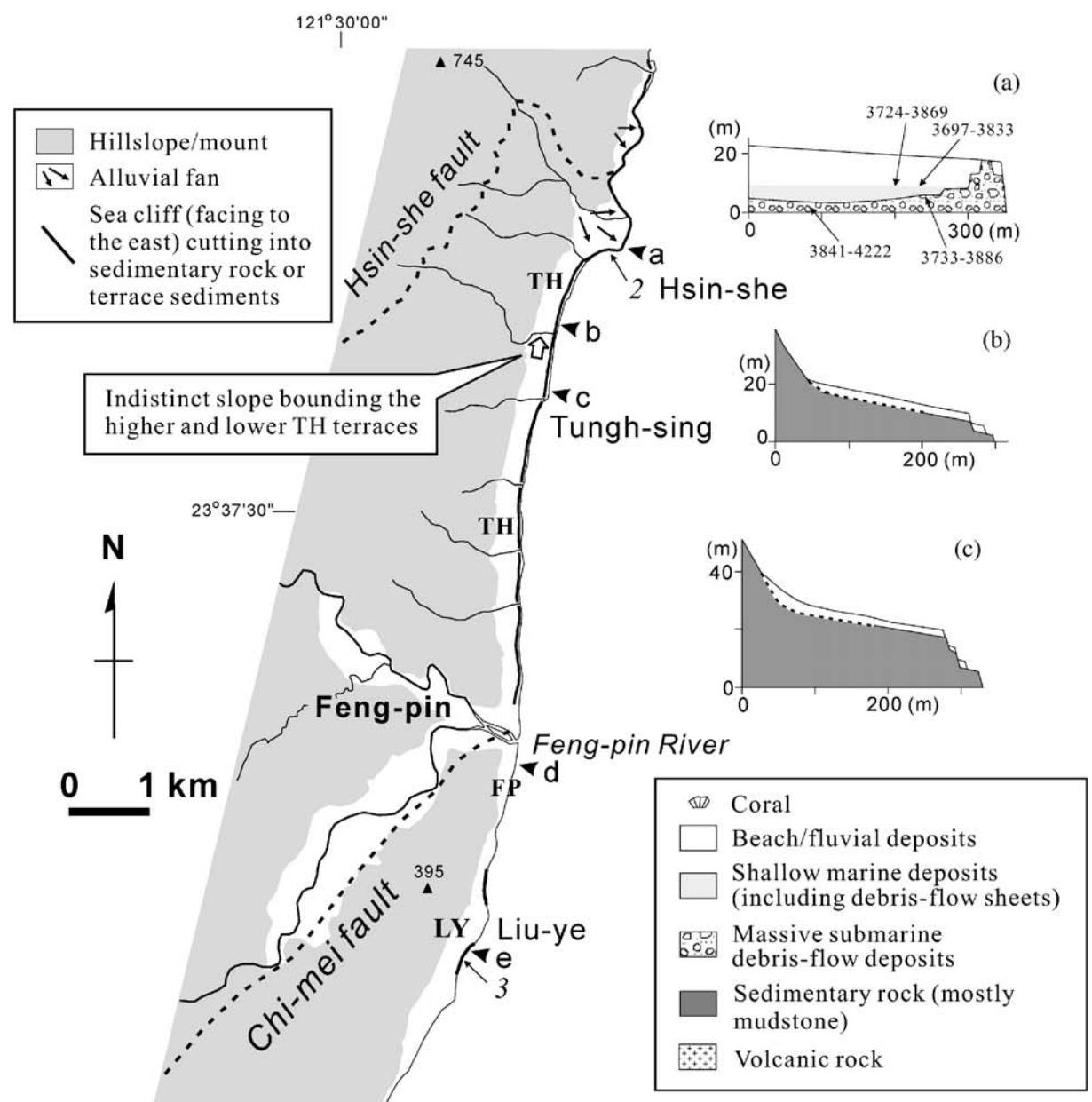

(d)

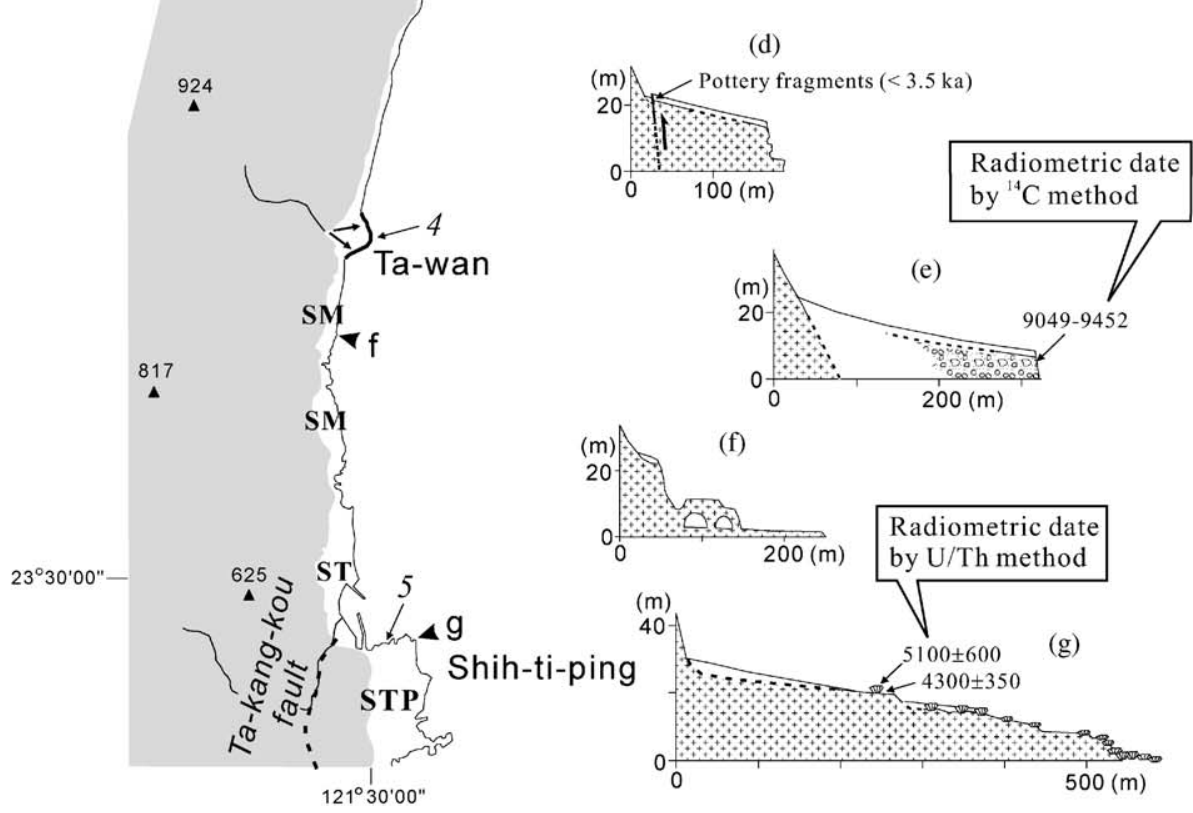

Fig. 4. Marine terraces from Hsin-she to Shih-ti-ping (for location see Fig. 2). Italic numerals are sites of dates referred in Fig. 3 and Table 1. Dates by radiocarbon method are expressed as $1 \sigma$ range of calibrated ages (cal. yr BP). 
Table 1

Radiometric dates ( $>3 \mathrm{ka}$ ) from the Hua-tung coast

\begin{tabular}{|c|c|c|c|c|c|c|c|c|c|c|c|c|}
\hline \multicolumn{2}{|c|}{ Location } & \multicolumn{4}{|l|}{ Sample } & \multicolumn{2}{|l|}{ C-14 age } & \multirow{2}{*}{$\begin{array}{l}\text { Calibrated } \\
\text { age(s) } \\
\text { (cal. yr BP) }\end{array}$} & \multirow{2}{*}{$\begin{array}{l}\mathrm{U} / \mathrm{Th} \text { age } \\
(\mathrm{yr} \mathrm{BP})\end{array}$} & \multirow[t]{2}{*}{ References ${ }^{\mathrm{f}}$} & \multirow{2}{*}{$\begin{array}{l}\text { Paleo-eustatic } \\
\text { sea level } \\
\text { elevation (m) } \\
\text { (Fig. 9) }\end{array}$} & \multirow{2}{*}{$\begin{array}{l}\text { Average } \\
\text { uplift rate } \\
(\mathrm{mm} / \mathrm{yr})\end{array}$} \\
\hline No. & Name & Material & $\begin{array}{l}\text { Elevation } \\
(\mathrm{m})\end{array}$ & $\begin{array}{l}\text { Occurrence or } \\
\text { depositional } \\
\text { setting }\end{array}$ & $\begin{array}{l}\text { Assumed } \\
\text { living or dep. } \\
\text { depth }(\mathrm{m})\end{array}$ & $\begin{array}{l}\text { Age } \\
\text { (yr BP) }\end{array}$ & Lab. no. & & & & & \\
\hline 1 & Ta-keng & calc. algae & 17.5 & $\begin{array}{l}\text { Growth } \\
\text { position }\end{array}$ & $<0$ & $6690 \pm 40^{\mathrm{c}}$ & NTU-2593 & $7154-7208$ & & B & $(-5)-(-16)$ & $\geq 3.1$ \\
\hline 2 & Hsin-she & Wood & 4 & $\begin{array}{l}\text { Nearshore/ } \\
\text { Offshore }\end{array}$ & $<(-4)$ & $3690 \pm 120^{\mathrm{c}}$ & NTU-1239 & $3841-4222$ & & A & $3-1$ & $>1.2$ \\
\hline 2 & Hsin-she & Wood & 5.5 & $\begin{array}{l}\text { Nearshore/ } \\
\text { Offshore }\end{array}$ & $<(-4)$ & $3560 \pm 40^{\mathrm{c}}$ & NTU-1684 & $3733-3886$ & & A & $3-1$ & $>1.7$ \\
\hline 2 & Hsin-she & Wood & 8.5 & Nearshore & $(-1)-(-3)$ & $3510 \pm 40^{\mathrm{c}}$ & NTU-1757 & $3697-3833$ & & A & $3-1$ & $1.7-2.8$ \\
\hline 2 & Hsin-she & Wood & 8 & Nearshore & $(-1)-(-3)$ & $3550 \pm 40^{c}$ & NTU-3503 & 3724-3869 & & A & $3-1$ & $\overline{1.6}-2.7$ \\
\hline 3 & Liu-ye & Wood & 7 & Offshore & $<(-10)$ & $8340 \pm 140^{\mathrm{c}}$ & & $9049-9452$ & & $\mathrm{C}$ & $(-17)-(-33)$ & $\geq 3.6$ \\
\hline 4 & Ta-wan & Wood & 5 & Nearshore & $(-1)-(-10)$ & $10460 \pm 60^{\mathrm{c}}$ & NTU-3738 & $12174-12795$ & & A & $(-52)-(-63)$ & $\overline{4.5-6.4}$ \\
\hline 5 & Shih-tip-ing & Coral & 22 & $\begin{array}{l}\text { Growth } \\
\text { position }\end{array}$ & $<0$ & & & & $5100 \pm 600$ & $\mathrm{H}$ & $3-(-4)$ & $>3.3$ \\
\hline 5 & Shih-ti-ping & Coral & 20 & $\begin{array}{l}\text { Growth } \\
\text { position }\end{array}$ & $<0$ & & & & $4300 \pm 350$ & $\mathrm{H}$ & $3-1$ & $\geq 3.6$ \\
\hline 6 & $\begin{array}{l}\text { Hsiu-ku-luan } \\
\text { R. }\end{array}$ & Peat & $21-22$ & Floodplain & $4-1$ & $11600 \pm 50^{\mathrm{c}}$ & NTU-3712 & $13431-13637$ & & A & $(-62)-(-75)$ & $\underline{5.8}-7.1$ \\
\hline 6 & $\begin{array}{l}\text { Hsiu-ku-luan } \\
\text { R. }\end{array}$ & Wood & 26 & Floodplain & $4-1$ & $9310 \pm 58^{\mathrm{c}, \mathrm{d}}$ & Wk-9980 & $10165-10365$ & & A & $(-24)-(-47)$ & $4.4-7.1$ \\
\hline 6 & $\begin{array}{l}\text { Hsiu-ku-luan } \\
\text { R. }\end{array}$ & Wood & 27 & Floodplain & $4-1$ & $9541 \pm 57^{\mathrm{c}, \mathrm{d}}$ & Wk-9981 & $10472-10878$ & & A & $(-32)-(-52)$ & $5.1-7.4$ \\
\hline 6 & $\begin{array}{l}\text { Hsiu-Ku-Luan } \\
\text { R. }\end{array}$ & Wood & 28.5 & $\begin{array}{l}\text { Floodplain/ } \\
\text { Growth } \\
\text { position }\end{array}$ & $2-1$ & $3830 \pm 30^{\mathrm{c}}$ & NTU-3756 & $4152-4274$ & & A & $3-1$ & $5.5-\underline{6.4}$ \\
\hline 7 & Pa-hsien-tung & Charcoal & 36.5 & Beach $^{\mathrm{a}}$ & $1-(-1)$ & $5240 \pm 260^{\mathrm{c}}$ & NTU-69 & $5722-6295$ & & $\mathrm{~J}$ & $3-(-8)$ & $\leq 8.0$ \\
\hline 7 & Pa-hsien-tung & Charcoal & 36.5 & Beach $^{\mathrm{a}}$ & $1-(-1)$ & $5340 \pm 260^{\mathrm{c}}$ & NTU-70 & $5768-6405$ & & $\mathrm{~J}$ & $3-(-9)$ & $\overline{<8.1}$ \\
\hline 7 & Pa-hsien-tung & Charcoal & 36.5 & Beach $^{\mathrm{a}}$ & $1-(-1)$ & $4970 \pm 250^{c}$ & NTU-71 & $5337-5943$ & & $\mathrm{~J}$ & $3-(-6)$ & $<8.2$ \\
\hline 8 & Ta-ba-lai & Wood & 40 & Nearshore & $(-1)-(-10)$ & $5070 \pm 50^{\mathrm{c}}$ & NTU-1122 & $5740-5903$ & & G & $3-(-6)$ & $\underline{6.4-9.8}$ \\
\hline 9 & San-chien-wu & Wood & 28 & Offshore & $<(-10)$ & $5230 \pm 30^{\mathrm{c}}$ & NTU-1253 & $5934-6020$ & & G & $2-(-7)$ & $>6.0$ \\
\hline 10 & Chang-kung & Wood & 6 & Offshore & $<(-10)$ & $7820 \pm 50^{\mathrm{c}}$ & NTU-1230 & $8495-8578$ & & G & $(-13)-(-26)$ & $\overline{>3.4}$ \\
\hline 11 & Chang-pin & Shell & 4 & Offshore & $<(-10)$ & $9250 \pm 120^{\mathrm{b}, \mathrm{d}}$ & GifA-91093 & 9824-9997 & & $\mathrm{C}$ & $(-22)-(-37)$ & $>3.6$ \\
\hline 11 & Chang-pin & Shell & 4 & Offshore & $<(-10)$ & $9300 \pm 110^{\mathrm{b}, \mathrm{d}}$ & GifA-90217 & $9846-10027$ & & $\mathrm{C}$ & $(-22)-(-37)$ & $>3.6$ \\
\hline 11 & Chang-pin & Shell & 4 & Offshore & $<(-10)$ & $8890 \pm 60^{c}$ & NTU-3107 & $9439-9535$ & & $\mathrm{~B}$ & $(-20)-(-34)$ & $>3.6$ \\
\hline 11 & Chang-pin & Shell & 11 & Offshore & $<(-10)$ & $8930 \pm 60^{c}$ & NTU-2048 & $9468-9607$ & & B & $(-20)-(-34)$ & $\geq 4.3$ \\
\hline
\end{tabular}




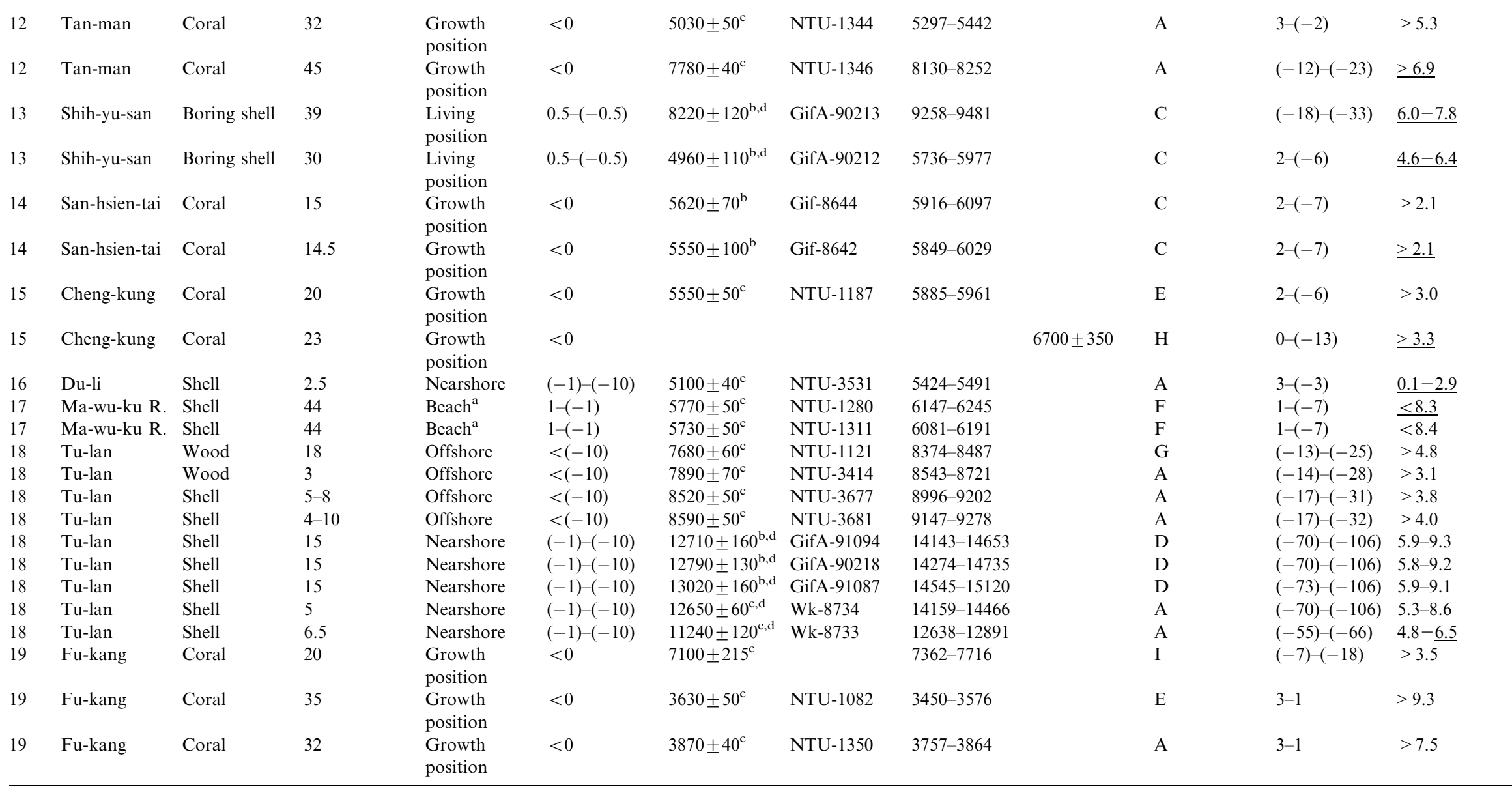

${ }^{\mathrm{a}}$ In culture bed.

${ }^{\mathrm{b} C a l c u l a t e d}$ using $5570 \mathrm{yr}$ as the half lift of ${ }^{14} \mathrm{C}$; subtracting the age-correction factor of $-540 \mathrm{yr}$ in Liew et al. (1993) and Pirazzoli et al. (1993).

${ }^{\mathrm{c}}$ Calculated using $5568 \mathrm{yr}$ as the half lift of ${ }^{14} \mathrm{C}$.

${ }^{\mathrm{d}}$ By accelerator mass spectrometry (AMS).

${ }^{\mathrm{e}}$ Expressed as $1 \sigma$ range; following Stuiver and Reimer (1993), assuming $\Delta R=0$ for marine samples.

${ }^{\mathrm{f}} \mathrm{A}=$ this study; $\mathrm{B}=$ Hsu et al. (1998); $\mathrm{C}=$ Liew et al. (1993); $\mathrm{D}=$ Pirazzoli et al. (1993); $\mathrm{E}=$ Chen et al. (1991); $\mathrm{F}=$ Huang (1991); $\mathrm{G}=$ Hsieh (1990); H= Lin (1989); $\mathrm{I}=$ Peng et al. (1977); J=Sung (1969).

${ }^{\mathrm{g}}$ Underlined where used in Fig. 10. 


\subsection{Shih-ti-ping to Chang-pin}

The major terrace (labeled KC) developed on this part of the coast is significantly higher and more continuous than the terraces to the north. This terrace is underlain mainly by volcanic bedrock, but extends landward across the Ta-kang-kou fault in some places (Fig. 5). Where the landward part of the terrace is cut into mudstone or the sheared Ta-kang-kou fault zone, it is wider and higher (the apparent shoreline angle is 35$40 \mathrm{~m}$ in elevation). The terrace is covered by thin beach gravel and dune sand (at least on the seaward part), and

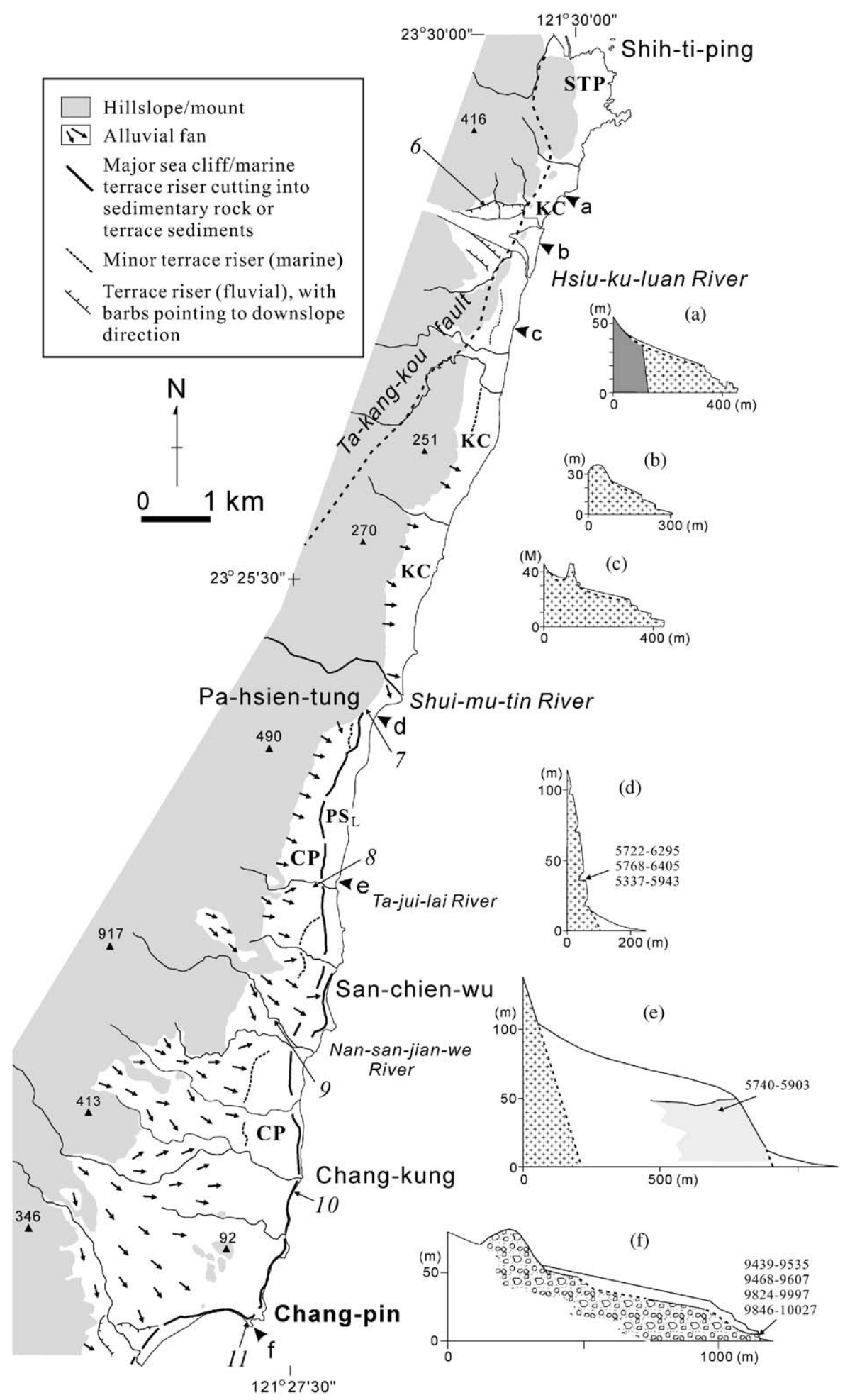

Fig. 5. Marine terraces from Shih-ti-ping to Chang-pin (for location see Fig. 2). Legends and notes as in Fig. 4. 
consists of several minor steps with sea notches. The highest sea notch observed, left on a volcanic sea stack, is $37 \mathrm{~m}$ high above sea level.

The Hsiu-ku-luan River, the largest and the only river cutting through the entire Coastal Range, crosses the $\mathrm{KC}$ terrace (Fig. 5). In the river mouth, thick fluvial sequences are exposed as planar stratified mud layers deposited in the floodplain environment and massive, boulder-bearing mud bodies probably derived from the adjacent hillslopes through mud flows. One kilometer from the shore, a peat formation at elevations $21-22 \mathrm{~m}$ is dated 13,431-13,637 cal. yr BP (Table 1, Location 6). Above it, plant fragments at elevations of 26 and $27 \mathrm{~m}$ are dated 10,165-10,365 and 10,472-10,878 cal. yr BP, respectively, which are inconsistent with their stratigraphic levels. We consider that the dated beds from 26 to $27 \mathrm{~m}$ in elevation were deposited during 10.1-10.9 ka. At the same site, these dated fine-grained sediments are sharply truncated on the top by a $0.5-\mathrm{m}$ thick channel gravel, which is further covered by overbank mud and sand ( $<4 \mathrm{~m}$ thick) of younger river-terrace deposits. At an elevation of $28.5 \mathrm{~m}$, tree trunks in growth position directly above the channel gravel are dated 4152 4274 cal. yr BP.

The $\mathrm{KC}$ terrace ends to the south with an abandoned alluvial fan at the mouth of the Shui-mu-tin River. From here to the south, a lower terrace (labeled $\mathrm{PS}_{\mathrm{L}}$ ) no more than $20 \mathrm{~m}$ in elevation occurs (Fig. 5), which grades seaward to the modern beaches and coastal dunes. On the adjacent volcanic cliff, series of sea caves (Pa-hsien-tung) at multiple elevations exist. Excavation of one of these caves, the Chao-ying cave, uncovered abundant Paleolithic relics within coarse beach sand at elevations of $36-37 \mathrm{~m}$, which are dated $5.3-6.4 \mathrm{ka}$ by Sung (1969) (Fig. 5, profile d).

In addition to the $\mathrm{PS}_{\mathrm{L}}$ terrace, which ends $6 \mathrm{~km}$ to the south with the modern sea cliff, the coast south from Pahsien-tung develops a higher major terrace (labeled CP), which continuously extends and merges with the extensive alluvial fans around Chang-pin (Fig. 5). The $\mathrm{CP}$ terrace is composed of thick shallow marine sediments in the lower part and beach/fluvial deposits on the top. No bedrock has been found underneath this terrace. The observed thickest marine sequence, from elevations $6 \mathrm{~m}$ to $43 \mathrm{~m}$, is exposed in the Ta-jui-lai River (Fig. 5), in which a debris-flow bed at an elevation of $40 \mathrm{~m}$ is dated $5740-5903 \mathrm{cal}$. yr BP. Two kilometers to the south and at an elevation of $28 \mathrm{~m}$, mud layers deposited in the offshore environment are dated 59346020 cal. yr BP in the Nan-san-jian-wu River. The region's highest beach gravel $(50-54 \mathrm{~m}$ in elevation) is also exposed in this river, at the inner edge of the $\mathrm{CP}$ terrace.

Like many other abandoned fan-deltas along the coast, the great one around Chang-pin (or the Changpin terrace) consists of submarine debris-flow/slumping deposits, which are truncated on the top by beach/fluvial sediments (Fig. 5, profile f). The submarine deposits were dated 8495-8578 cal. yr BP from wood and 9.4 $10.0 \mathrm{ka}$ from marine shells (Liew et al., 1993; Hsu et al., 1998). The observed highest beach sediments on the terrace are $40-45 \mathrm{~m}$ in elevation.

\subsection{Chang-pin to San-hsien-tai}

The area between Chang-pin and Tan-man displays the coast's most continuous binary major terraces (Fig. 6). The higher one is the southward extension of the CP terrace around Chang-pin and has a landward

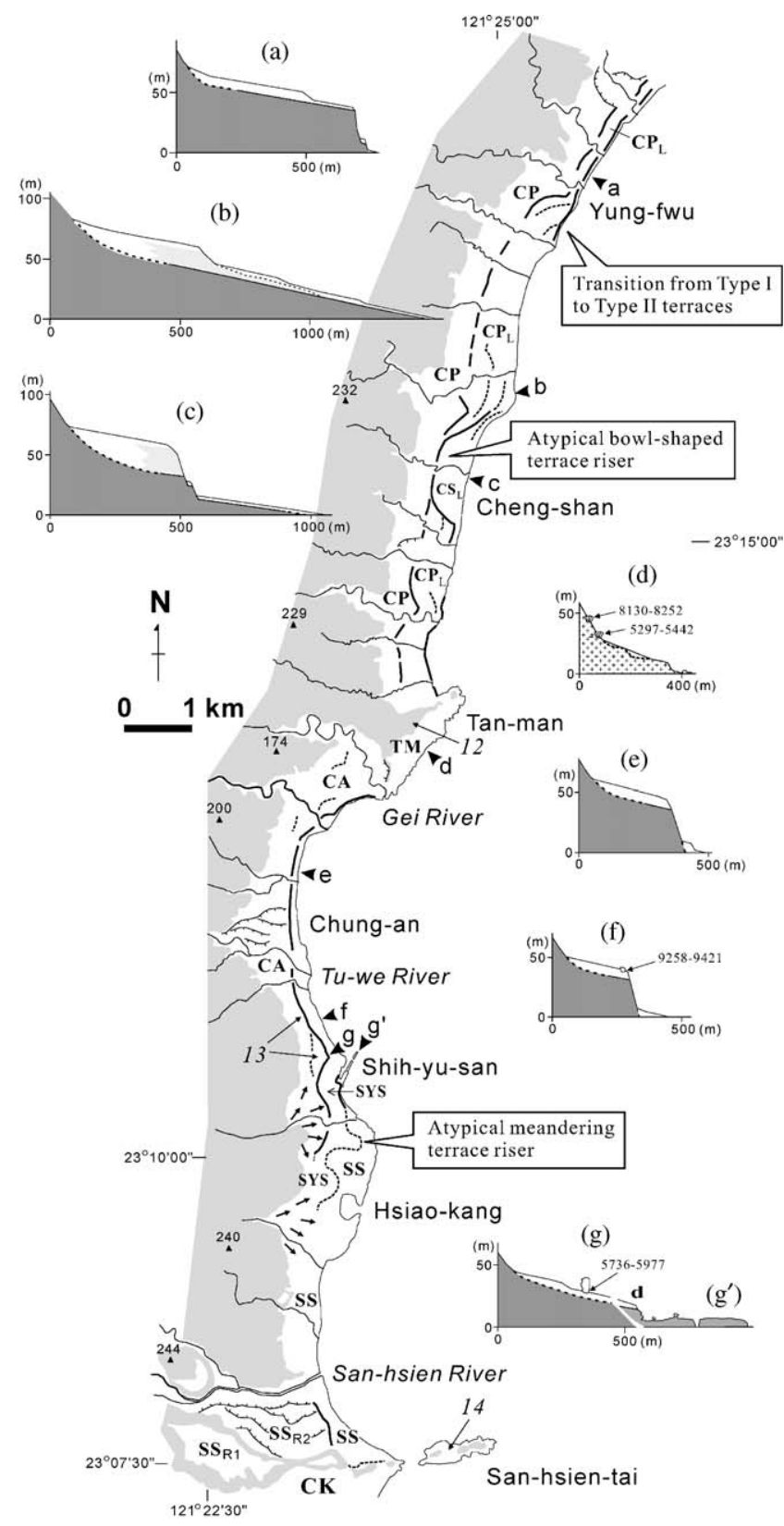

Fig. 6. Marine terraces from Chang-pin to San-hsien-tai (for location see Fig. 2). Legends and notes as in Figs. 4 and 5. 
edge at $75-80 \mathrm{~m}$ in elevation. The $\mathrm{CP}$ terrace here consists of nearshore sand and gravel, which is less than $10 \mathrm{~m}$ thick near Yung-fwu but at least $25 \mathrm{~m}$ thick around Chen-shan (Fig. 6, profiles a-c). The observed highest marine sediments, exposed on the outer part of the terrace near Chen-shan, are $55-60 \mathrm{~m}$ in elevation.

The lower major terrace (labeled $\mathrm{CP}_{\mathrm{L}}$ ), with its landward edge $45-50 \mathrm{~m}$ in elevation, is narrow $(200 \mathrm{~m}$ wide) north of Yung-fwu, where it is bounded seaward by a $20-25-\mathrm{m}$-high sea cliff (Type I terrace). To the south, the terrace widens to $500 \mathrm{~m}$ in width and grades seaward to the modern beaches (Type II terrace). Around Chen-shan, the $\mathrm{CP}_{\mathrm{L}}$ terrace is trimmed by a bowl-shaped terrace riser curving from about the modern coast to the foot of the CP terrace (Fig. 6). Below this riser, another terrace $(<20 \mathrm{~m}$ in elevation; labeled $\mathrm{CS}_{\mathrm{L}}$ ) is developed (Fig. 6). The marine and fluvial sediments exposed on the $\mathrm{CP}_{\mathrm{L}}$ terrace are much thinner $(<10 \mathrm{~m})$ than those on the $\mathrm{CP}$ terrace. These sediments overlie mudstone platforms, which continuously extend underneath the terrace risers between the $\mathrm{CP}$ and $\mathrm{CP}_{\mathrm{L}}$ terraces. In other words, the sediments on both the $\mathrm{CP}$ and $\mathrm{CP}_{\mathrm{L}}$ terraces overlie a single mudstone platform (Fig. 6, profiles a and b).

Both the $\mathrm{CP}$ and $\mathrm{CP}_{\mathrm{L}}$ terraces end to the south with a volcanic ridge near Tan-man. On this ridge, remnants of beach gravel as high as $57 \mathrm{~m}$ in elevation were found. To the south, the coast develops one step of a major terrace underlain by volcanic rock. This terrace (labeled TM) is significantly lower (maximum: $30 \mathrm{~m}$ in elevation) than the $\mathrm{CP}$ and $\mathrm{CP}_{\mathrm{L}}$ terraces to the north. On the adjacent hillslope, fossil corals at 32 and $45 \mathrm{~m}$ in elevation are dated 5297-5442 and 8130-8252 cal. yr BP, respectively (Table 1, Location 12).

The TM terrace ends to the south with a (volcanic?) ridge on the northern bank of the Gei River. To the south, the coast develops a Type I major terrace (labeled CA) (Fig. 6). It has a maximum elevation of $70-75 \mathrm{~m}$, and is bounded seaward by a terrace riser up to $35 \mathrm{~m}$ in height. The terrace narrows to the south, and its landward edge gradually drops to $45-50 \mathrm{~m}$ in elevation before it ends with an alluvial fan near Shih-yu-san. Near Chung-an, the CA terrace is trimmed by a series of terrace risers resulting from the southward migration of the Tu-we River (Fig. 6). To the south, the marine/ fluvial sediments covering the CA terrace commonly incorporate limestone boulders of various sizes. North of Shih-yu-san, boring shells ( $39 \mathrm{~m}$ in elevation) on a limestone boulder are dated $9258-9481 \mathrm{cal}$. yr BP by Liew et al. (1993). A kilometer to the south, a giant limestone boulder stands on the CA terrace, on which boring shells at an elevation of $30 \mathrm{~m}$ are dated 57365977 cal. yr BP (Liew et al., 1993).

Below the CA terrace, the coast between Shih-yu-san and Hsiao-kang develops another two major terraces (labeled SYS and SS) separated by a minor, meandering terrace riser (Fig. 6). The higher SYS terrace cuts landward into an alluvial fan, and has an apparent shoreline angle at $30-35 \mathrm{~m}$ in elevation around Shih-yusan. South of Hsiao-kang, the SYS terrace is obscured by other alluvial fans and merges with the lower SS terrace (Fig. 6). The SS terrace consists of coral platforms (undated) around Hsiao-kang. To the south, the SS terrace, less than $20 \mathrm{~m}$ in elevation, grades seaward to the modern beaches and sand dunes. The SS terrace continuously extends across the San-hsien River and ends with a volcanic ridge at San-hsien-tai cape.

The SS terrace north of the San-hsien River, unclear underneath the surface, is bounded landward by hillslopes composed of mudstone. To the south, the terrace truncates a flight of river terraces left by the northward migration of the San-hsien River (Fig. 6). These river terraces, consisting of thick fluvial gravel, can be grouped into at least two major levels; the lower one (labeled $\mathrm{SS}_{\mathrm{R} 2}$ ) is $20-25 \mathrm{~m}$ high above the $\mathrm{SS}$ terrace. The exposed minimum elevation of the fluvial gravel underlying the $\mathrm{SS}_{\mathrm{R} 2}$ terrace is $19 \mathrm{~m}$ above sea level. No bedrock has been found underneath this gravel in the coastal area. Two kilometers upstream from the river mouth, however, a mudstone stratum $15-20 \mathrm{~m}$ high above the modern channel is continuously exposed underneath the $\mathrm{SS}_{\mathrm{R} 2}$ terrace. A mud layer directly above this bedrock stratum is dated $5744-5907 \mathrm{cal}$. yr BP (Hsieh et al., 1994).

The cape of San-hsien-tai, as well as its neighboring island, is underlain by volcanic rock and develops erosional benches lower than $20 \mathrm{~m}$ in elevation. Fossil corals on these benches have been dated by many investigators (Hsu et al., 1973; Peng et al., 1977; Lin, 1989; Liew et al., 1993; Vita-Finzi and Lin, 1998). The oldest dates, 5916-6097 and 5849-6029 cal. yr BP by Liew et al. (1993), are derived at elevations of 14-15 m.

\subsection{San-hsien-tai to $M a-w u-k u$ river}

A $1.5 \mathrm{~km}$-wide major terrace (labeled CK), underlain by mudstone, is developed along the coast between Sanhsien-tai and Cheng-kung (Fig. 7). It has a landward edge (trimming the $\mathrm{SS}_{\mathrm{R} 1}$ terrace) $30-35 \mathrm{~m}$ in elevation south of San-hsien-tai, which rises southward to 45$50 \mathrm{~m}$ in elevation. North of Cheng-kung, instead of dipping to the sea, parts of this terrace atypically incline toward the mouth of the Hsin-kang River, which suggests that this river mouth could have been warped down (Fig. 7). In contrast, the terrace west of Chengkung could have been domed up, along an east-westoriented axis (Fig. 7). Here, the landward edge of the $\mathrm{CK}$ terrace is at $60-70 \mathrm{~m}$ in elevation. Fossil corals occur between the San-hsien-tai cape and the Hsin-kang River, and have been substantially dated (Hsu et al., 1973; Lin, 1989; Chen et al., 1991; Yamaguchi and Ota, 2001). The oldest dates, $6700 \pm 350 \mathrm{yr}$ BP (U/Th age) by Lin (1989) 


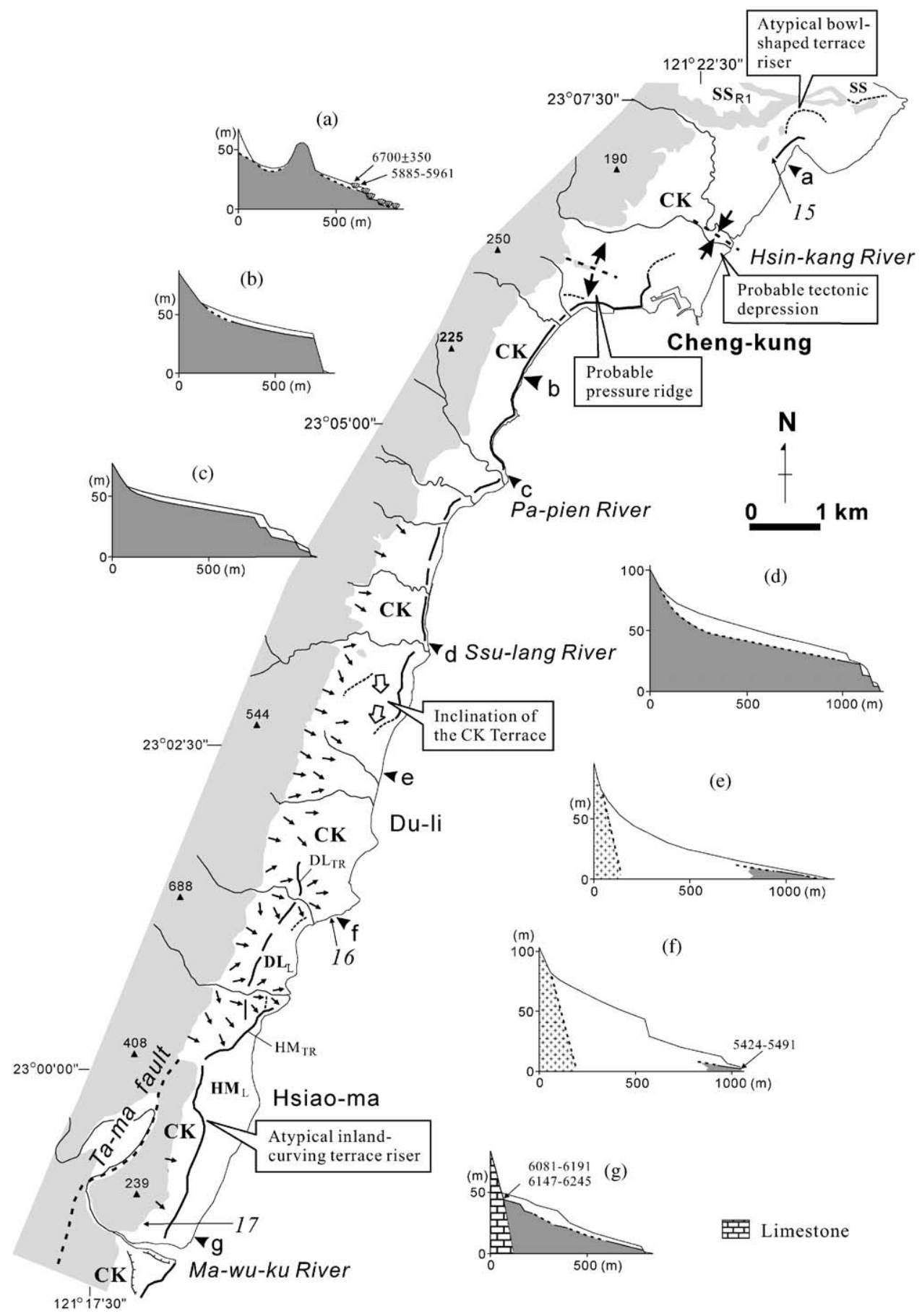

Fig. 7. Marine terraces from San-hsien-tai to the Ma-wu-ku River (for location see Fig. 2). Legends and notes as in Figs. 4 and 5.

and 5885-5961 cal. yr BP by Chen et al. (1991), are derived at elevations 23 and $20 \mathrm{~m}$, respectively.

South of Cheng-kung, the CK terrace narrows to $500-700 \mathrm{~m}$ in width and changes to a Type I terrace (Fig. 7). In the Pa-pien River valley, a shoreline angle at $50-55 \mathrm{~m}$ in elevation is exposed. Farther south, the terrace widens. Its landward edge rises to more than $70 \mathrm{~m}$ in elevation and is covered by alluvial fans. The terrace then declines from the Ssu-lang River to the south, with its bounding sea cliff lowering, curving inland and merging into a coastal plain more than $1 \mathrm{~km}$ in width around Du-li (Fig. 7, from profiles d to e). South of Duli, a 15-20-m high terrace riser (labeled $\mathrm{DL}_{\mathrm{TR}}$ ) occurs and separates the terrace into two major steps (Fig. 7). The higher terrace is covered by alluvial fans that are trimmed by this terrace riser. Where major rivers cross this terrace riser, younger alluvial fans also are developed on the lower terrace (labeled $\mathrm{DL}_{\mathrm{L}}$ ) (Fig. 7). 
Exposures along the modern sea cliff show that the $\mathrm{DL}_{\mathrm{L}}$ terrace is underlain by a mudstone platform, which is covered by poorly sorted gravel $(<0.5 \mathrm{~m}$ thick), including some giant volcanic boulders. This gravel consists of both angular and well-rounded clasts, as well as abundant marine shells. The gravel, therefore, is likely an erosional remnant of fluvial-driven debris-flow deposits, which had been transported across the beach and deposited in the shore-face environment. Shells within this gravel, $2.5 \mathrm{~m}$ high above the sea level, are dated 5424-5491 cal. yr BP (Table 1, Location 16).

The CK terrace continuously extends to the south, but its landward edge steps to the east where it crosses the Ta-ma fault around Hsiao-ma (Fig. 7). Here, the CK terrace abruptly narrows (to $<100 \mathrm{~m}$ in width), as a terrace riser (labeled $\mathrm{HM}_{\mathrm{TR}}$ ) extending from the modern coast curves landward and trims most of the terrace (Fig. 7). The $\mathrm{HM}_{\mathrm{TR}}$ terrace riser continues to the Mawu-ku River, and it separates another lower major terrace (labeled $\mathrm{HM}_{\mathrm{L}}$ ) from the $\mathrm{CK}$ terrace. The $\mathrm{CK}$ terrace south of Hsiao-ma, with an apparent shoreline angle at $45-50 \mathrm{~m}$ in elevation, is bounded landward by a cliff composed of volcanic rock or limestone, on which series of caves (the Hsiao-ma cave) are developed along the edge of the terrace. As in the Chao-ying cave, abundant Paleolithic relics were uncovered in these caves, in which marine shells associated with beach sand are dated 6147-6245 and 6081-6191 cal. yr BP at an elevation of $44 \mathrm{~m}$ (Huang, 1991). Both the CK and $\mathrm{HM}_{\mathrm{L}}$ terraces (combined as a Type II terrace) are underlain by a mudstone platform with some minor steps, as exposed along the Ma-wu-ku River. These steps, however, appear to be irrelevant to the $\mathrm{HM}_{\mathrm{TR}}$ terrace riser on the surface (Fig. 7, profile g).

\subsection{Ma-wu-ku river to Tu-lan}

The $\mathrm{HM}_{\mathrm{L}}$ terrace and the $\mathrm{HM}_{\mathrm{TR}}$ terrace riser end in the Ma-wu-ku River, which left a series of fluvial terraces on the southern bank (Fig. 7). The relatively gentle modern coast north of the river is replaced to the south by a sea cliff (labeled $\mathrm{LC}_{\mathrm{TR}}$ ) $20 \mathrm{~m}$ in height (Fig. 8). The CK terrace, however, appears to maintain the same elevation as it extends across the river (but changes to a Type I terrace). The terrace crosses the Ta-ma fault near Jin-jun (Fig. 8). Here, the shoreline angle, cutting into mudstone, is $45-50 \mathrm{~m}$ in elevation (Fig. 8, profile a).

To the south, the CK terrace narrows to $300 \mathrm{~m}$ in width where the $\mathrm{LC}_{\mathrm{TR}}$ sea cliff increases in height to $50 \mathrm{~m}$. Here, the terrace, buried by thick alluvium, has a landward edge at more than $80 \mathrm{~m}$ in elevation. Farther south, the CK terrace gradually widens (to more than $1 \mathrm{~km})$ as the $\mathrm{LC}_{\mathrm{TR}}$ sea cliff lowers. Here, the observed maximum elevation of beach gravel, exposed about $300 \mathrm{~m}$ away from the mountain along the Chi-li River, is $40 \mathrm{~m}$ (Fig. 8, profile b). The CK terrace continuously widens to the south. Near Lung-chang, the $\mathrm{LC}_{\mathrm{TR}}$ sea cliff curves inland, below which another major terrace (labeled $\mathrm{LC}_{\mathrm{L}}$ ) starts (Fig. 8). Both the $\mathrm{LC}_{\mathrm{L}}$ terrace and the fan-covered $\mathrm{CK}$ terrace (combined as a Type II terrace) continuously extend to the Yang River.

The CK and $\mathrm{LC}_{\mathrm{L}}$ terraces converge south from the Yang River (Fig. 8). At a higher level, another fancovered major terrace (labeled $\mathrm{YC}_{\mathrm{H}}$ ) occurs. The highest marine sediments observed in this terrace, $1 \mathrm{~km}$ from the mountain, are $40-45 \mathrm{~m}$ in elevation. The separation between the $\mathrm{YC}_{\mathrm{H}}$ terrace and the lower $\mathrm{CK}$ terrace does not last for more than $2 \mathrm{~km}$ before the two terraces converge with each other into the area's largest fan surface around Tu-lan (Fig. 8).

The great Tu-lan fan-delta (or the Tu-lan terrace) consists of a mudstone platform at the base (Fig. 8, profile $d-d^{\prime}$ ). This platform is exposed as high as 20 $25 \mathrm{~m}$ in the Hsin River and continuously extends underneath the sea level $500 \mathrm{~m}$ from the tip of the terrace. Above this platform, nearshore sand as thick as $15 \mathrm{~m}$ is exposed along the Hsin River. About $500 \mathrm{~m}$ to the east, this sand unit was dated $14.1-15.1 \mathrm{ka}$ by Pirazzoli et al. (1993) at an elevation of $15 \mathrm{~m}$. Farther east, this sand is less than $5 \mathrm{~m}$ thick, and is dated 12,63812,891 and 14,159-14,466 cal. yr BP at elevations 6.5 and $5 \mathrm{~m}$, respectively (Table 1 , Location 18). This sand unit is overlain by submarine debris-flow/slumping deposits up to $25 \mathrm{~m}$ in thickness. These deposits, dated 8.3-8.7 ka from wood and 8.9-9.3 ka from marine shells (Table 1, Location 18), are truncated on the top by beach/fluvial sequences, which extend seaward and merge with the modern beach at the tip of the terrace. The observed highest beach sediments, exposed along the Hsin River, are $50 \mathrm{~m}$ above the sea level. Here, beach gravel from elevations $42-46 \mathrm{~m}$ contains abundant pottery fragments, which pertain to the Neolithic culture emerging later than $4 \mathrm{ka}$ (Liu and Yen, 2000).

\subsection{Tu-lan to Fu-kang}

The extensive Tu-lan terrace increases in height to the south and ends with hills. The following 1-km-long coast, underlain by mudstone, is narrow and does not develop distinct marine terraces (Figs. 3 and 8). Even so, some beach remains as high as $55-60 \mathrm{~m}$ are preserved on the hillslope near Juin-jen (Fig. 8). To the south, the hillslope is cut by a terrace (labeled FK) several hundred meters in width and up to $70-75 \mathrm{~m}$ in elevation (Fig. 3). This terrace widens to more than $1 \mathrm{~km}$ south of $\mathrm{Yu}-$ chang, where its landward edge lowers to $60-65 \mathrm{~m}$ in elevation. Farther south, the FK terrace continuously widens and grades seaward to the rocky coast composed of sandstone platforms. North of Fu-kang, fossil corals on these platforms have been dated (Peng et al., 1977; Lin, 1989; Chen et al., 1991; Yamaguchi and Ota, 2001). The oldest age, $7362-7716$ cal. yr BP, is derived at an 


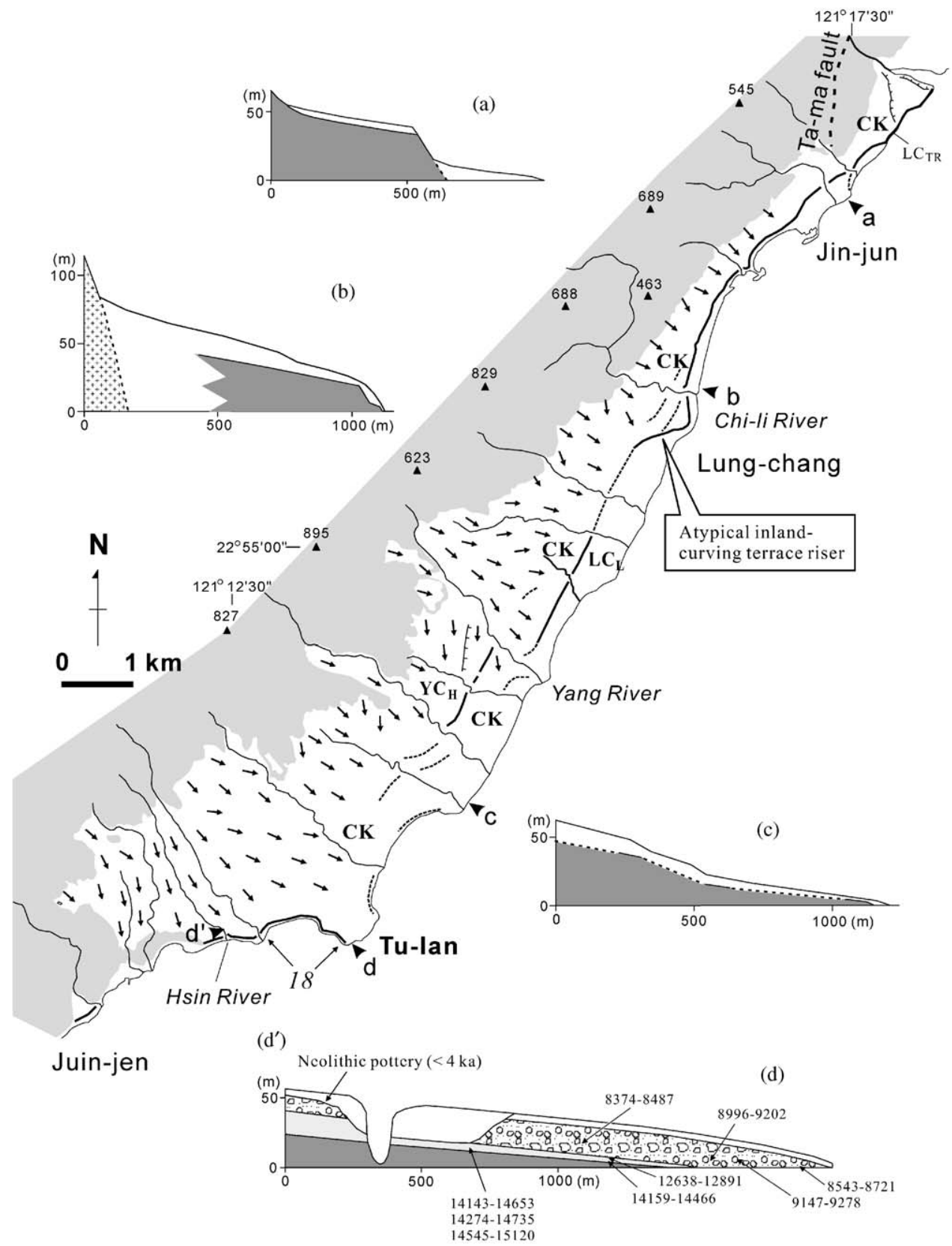

Fig. 8. Marine terraces from the Ma-wu-ku River to Tu-lan (for location see Fig. 2). Legends and notes as in Figs. 4 and 5.

elevation $20 \mathrm{~m}$ above sea level by Peng et al. (1977). The highest dated coral (at about $35 \mathrm{~m}$ in elevation), however, is reported as 3450-3576 cal. yr BP by Chen et al. (1991). We also obtained a date of 3757-3864 cal. $\mathrm{yr} \mathrm{BP}$ at an elevation of $32 \mathrm{~m}$ (Table 1, Location 19).

\section{Uplift derived from radiometric dates}

\subsection{Deglacial sea-level datums}

We first refer the coast's post-glacial (0-10 ka) eustatic sea-level datums to the sea-level curve constructed by
Chen and Liu (2000) (Fig. 9). The first half of this curve $(0-4.8 \mathrm{ka})$ is based on the dating of coral platforms in the Penghu Islands west of Taiwan (Chen and Liu, 1996). During this period, the sea level fell gradually from its maximum of $2.3 \mathrm{~m}$ above the modern sea level (i.e. $+2.3 \mathrm{~m}$ ). We assume that the sea level during $3-5 \mathrm{ka}$ has an uncertainty of $+2 \pm 1 \mathrm{~m}$. The second half of the curve $(4.8-10 \mathrm{ka})$ is constructed by smoothly connecting the $4.8 \mathrm{ka}$ sea level to the sea levels of $-2 \pm 4$ and $-30 \pm 7 \mathrm{~m}$ at 6 and $10 \mathrm{ka}$, respectively, which are averages of the sea levels reported elsewhere around the Pacific (Chen and Liu, 2000; and the references therein). Based on this curve (and its uncertainties), the 


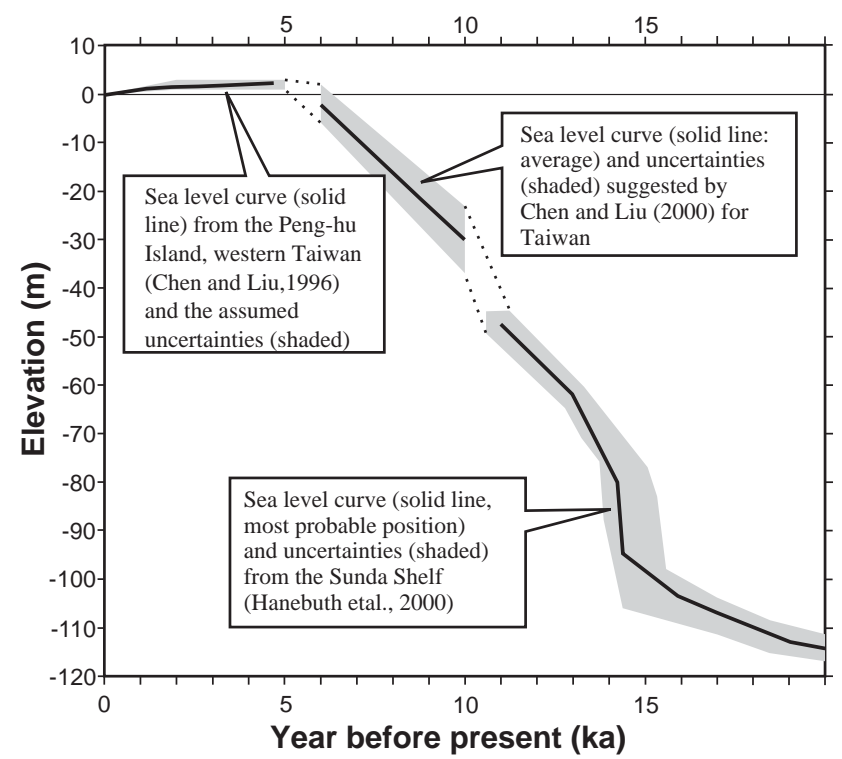

Fig. 9. Eustatic sea-level curve (and uncertainties) referred in this study.

rising sea level during 10-6 ka has an average rate of $7 \mathrm{~mm} / \mathrm{yr}$ and is unlikely to exceed $10 \mathrm{~mm} / \mathrm{yr}$.

We then assume that the coast's eustatic sea level prior to $11 \mathrm{ka}$ was equivalent to the sea level in the Sunda Shelf (Indonesia), one of the most reliable lateglacial sea level records documented (Hanebuth et al., 2000) (Fig. 9). The uncertainties in determining this sea level curve also are included. This curve (and its uncertainties) indicates that the rate of the sea-level rise is $8-9 \mathrm{~mm} / \mathrm{yr}$ during $13.5-11 \mathrm{ka}$ and $3 \mathrm{~mm} / \mathrm{yr}$ from the last glacial maximum to about $15 \mathrm{ka}$; in between, the rapid rise of sea level ( $>20 \mathrm{~mm} / \mathrm{yr}$ ), which corresponds to the meltwater pulse 1A (Fairbanks, 1989), has a great uncertainty of $-70 \mathrm{~m}$ to $-106 \mathrm{~m}$ (Fig. 9). Finally, we directly connect this sea level curve and the curve constructed by Chen and Liu (2000) (and their uncertainties) to obtain the sea level datums (and their possible ranges) during 11-10 ka (Fig. 9). The sea-level curve thus derived (average $18 \mathrm{~mm} / \mathrm{yr}$ in rate) is the steepest since $13.5 \mathrm{ka}$, which may correspond to the meltwater pulse 1B of Fairbanks (1989).

\subsection{Other assumptions}

A great portion of the dates available in the coast is derived from marine fossils (coral, boring shell, and algae) in living positions. Among them, the boring shells drilled their holes in the intertidal zone. We assume that they live within a water depth $\pm 0.5 \mathrm{~m}$ with respect to the mean sea level. The dated corals, lying on bedrock, are all solitary and their living water depths are unclear. The uplift rates derived from them (and algae) are considered as lower bounds.
Other dates come mainly from reworked wood and marine shells within marine sequences. The wood samples are exclusively associated with muddy, fluvialdriven debris-flow deposits, despite their common occurrence on the modern beaches (and fluvial channels). This promotes our confidence that these wood samples, once transported, must have been quickly buried and, therefore, preserved in a reduced environment. The sediments thus dated are referred to as being deposited in nearshore or offshore environments, depending on whether they show the effects of wave processes. We assume that, without other constraints, the nearshore environment has a water depth of $1-10 \mathrm{~m}$, and the offshore environment, greater than $10 \mathrm{~m} \mathrm{(a}$ typical wave base). In the Hsin-she terrace, the dated highest nearshore deposits are $1-2 \mathrm{~m}$ below the fluvial channel deposits. Because the boundary between the two sequences is transitional (i.e. no sign of depositional gap), we assume that the dated nearshore sediments were deposited at a water depth of $1-3 \mathrm{~m}$ below the mean sea level.

We obtained dates from beach deposits, which provide more precise paleo-sea level positions, only at the Chao-ying and Hsiao-ma caves. We assume that these beach beds were deposited $\pm 1 \mathrm{~m}$ relative to the mean sea level. Because the dates at the two caves are from cultural relics (charcoal and marine shells), they yield minimum ages of the deposition and, therefore, maximum uplift rates.

We also obtained dates from fluvial sediments deposited in the Hsiu-ku-luan River mouth. The modern Hsiu-ku-luan River downstream from these dated sediments (1 km from the shore) has a gradient of less than $0.1 \%$. This river gradient should not have significantly changed since the oldest date $(13.6 \mathrm{ka})$, given that the marine terrace $(\mathrm{KC})$ on the shore is only $300 \mathrm{~m}$ in width. The modern floodplain in the river mouth is less than $4 \mathrm{~m}$ in height. We thus assume that the dated peat and plant fragments from the overbank mud were deposited at an elevation $1-4 \mathrm{~m}$ above the sea level. For the dated in situ tree trunks, we assume that they were deposited at an elevation 1-2 $\mathrm{m}$ above the sea level, because they are located directly above the channel gravel.

\subsection{Results}

Our inferred uplift rates at multiple sites of the coast are listed in Table 1 and summarized in Fig. 10. These rates all show great uncertainties (or only upper or lower bounds), resulting from the great ranges of our assumed eustatic sea-level datums and living/depositional depths of the dated samples. We assume that these uncertainties suitably cover those from other sources, such as tidal ranges $(1 \mathrm{~m})$, surveying errors, sample reworking and calibration of radiocarbon ages (especially for marine samples). 


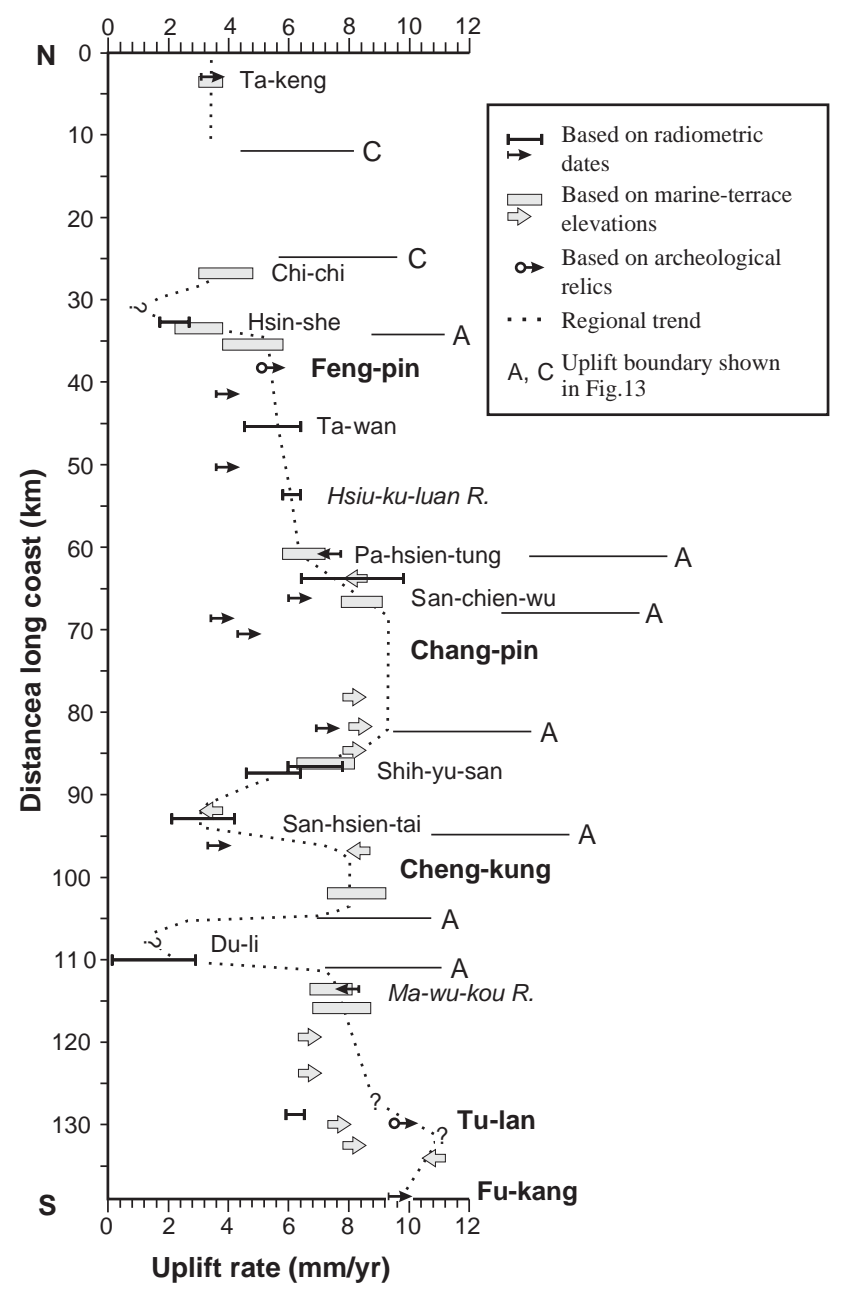

Fig. 10. Summary of Holocene uplift pattern and rates (with uncertainties) along the Hua-tung Coast. Starting point of each arrow shows upper or lower limit of the rate. Where the terraces are wide, only uplifts derived from the inner parts of the terraces are shown. See Tables 1 and 2 for data values.

As shown in Fig. 10, the northernmost part of the coast around Ta-keng is uplifted at a rate of at least $3.1 \mathrm{~mm} / \mathrm{yr}$. The uplift rate is $1.7-2.7 \mathrm{~mm} / \mathrm{yr}$ at Hsin-she, and reaches $4.5-6.4$ and $5.8-6.4 \mathrm{~mm} / \mathrm{yr}$ at Ta-wan and the Hsiu-ku-luan River, respectively. The uplift rate increases to $8.0-9.8 \mathrm{~mm} / \mathrm{yr}$ around San-chien-wu, but decreases to $4.6-6.4 \mathrm{~mm} / \mathrm{yr}$ around Shih-yu-san. The uplift rate is at least $2.1 \mathrm{~mm} / \mathrm{yr}$ at San-hsien-tai. Here, assuming that the thick fluvial sediments (minimum elevation $<19 \mathrm{~m}$ ) of the $\mathrm{SS}_{\mathrm{R} 2}$ terrace were deposited since 5744-5907 cal. yr BP (i.e. synchronously with the dated $\mathrm{SS}_{\mathrm{R} 2}$ terrace about $3 \mathrm{~km}$ upstream), we obtain a maximum uplift rate of $4.2 \mathrm{~mm} / \mathrm{yr}$. Farther south, the uplift rate is at least $3.3 \mathrm{~mm} / \mathrm{yr}$ around Cheng-kung, and would not exceed $2.9 \mathrm{~mm} / \mathrm{yr}$ around Du-li. The uplift rate is less than $8.3 \mathrm{~mm} / \mathrm{yr}$ north of the Ma-wu-ku River, $5.9-6.5 \mathrm{~mm} / \mathrm{yr}$ (or more) at Tu-lan, and is greater than $9.3 \mathrm{~mm} / \mathrm{yr}$ around Fu-kang.

\section{Uplift derived from marine-terrace elevations}

\subsection{Origin of major terraces and uplift rates}

Most of the terraces along the Hua-tung coast show one major step (Fig. 3). Even at some places, such as Chang-pin to Tan-man, where more than one step of major terraces is developed, the terraces are underlain by a single mudstone platform (Fig. 6). The mudstone platforms underlying the terraces (Figs. 6-8) appear to be wider $(>500 \mathrm{~m})$, higher ( $>10 \mathrm{~m}$ in relief), and steeper $\left(>1^{\circ}\right.$ or $\left.2^{\circ}\right)$ than typical abrasion platforms in other coastal areas (Bradley, 1958). The mudstone platforms in the Hua-tung coast, therefore, are likely to have been created during progressive submergence (Bradley and Griggs, 1976). Where bedrock is absent, such as in the CP terrace around San-chien-wu (Fig. 5), the thick terrace sediments show a single transgressive/regressive sequence (Hsieh, 1990). All these suggest that the origin of these terraces is related to a single cycle of sea-level change, which is reasonably linked to the deglacial sealevel history. Specifically, the broad mudstone platforms were eroded, and the marine sediments deposited, when the rising late- to post-glacial sea level slightly out-raced the tectonic uplift (e.g., Hull, 1987; Ota et al., 1988). The shoreline angles were created when the sea-level rise had the same rate as the tectonic uplift (i.e. when the relative sea level reached the highest stand) (Lajoie, 1986). After the slowly moving eustatic sea level no longer kept pace with the tectonic uplift, the terraces emerged and the shoreline prograded. During this period, coastal erosion of any reason could create terrace risers, resulting in more than one step of major terraces.

We apply this model and the eustatic sea-level curve assumed above to determine the uplift rates of the coast where the elevations of the shoreline angles, or the highest marine deposits, are known. Fig. 11a shows an example of this application. We only use the shoreline angles cutting into sedimentary rock for this purpose. This is because, given that Holocene fossil corals or beach remains are observed on hillslopes high above some volcanic-rock-based terraces, the shoreline angles of these terraces are unlikely to have been created during the maximum of the relative sea level. Perhaps, due to the general narrowness and steepness of the coast made up of volcanic rock, incoming wave energy may have frequently been reflected, so that it did not leave obvious topographic marks on the coast under certain sea-level conditions.

The results of our approach are summarized in Table 2 and Fig. 10. These results agree with the uplift rates derived from radiometric dates, and in most cases, further constrain the uplift rates of the dated sites (Fig. 10). This promotes our confidence that terraces composed of sedimentary rock, with its low resistance to erosion, could suitably document the 


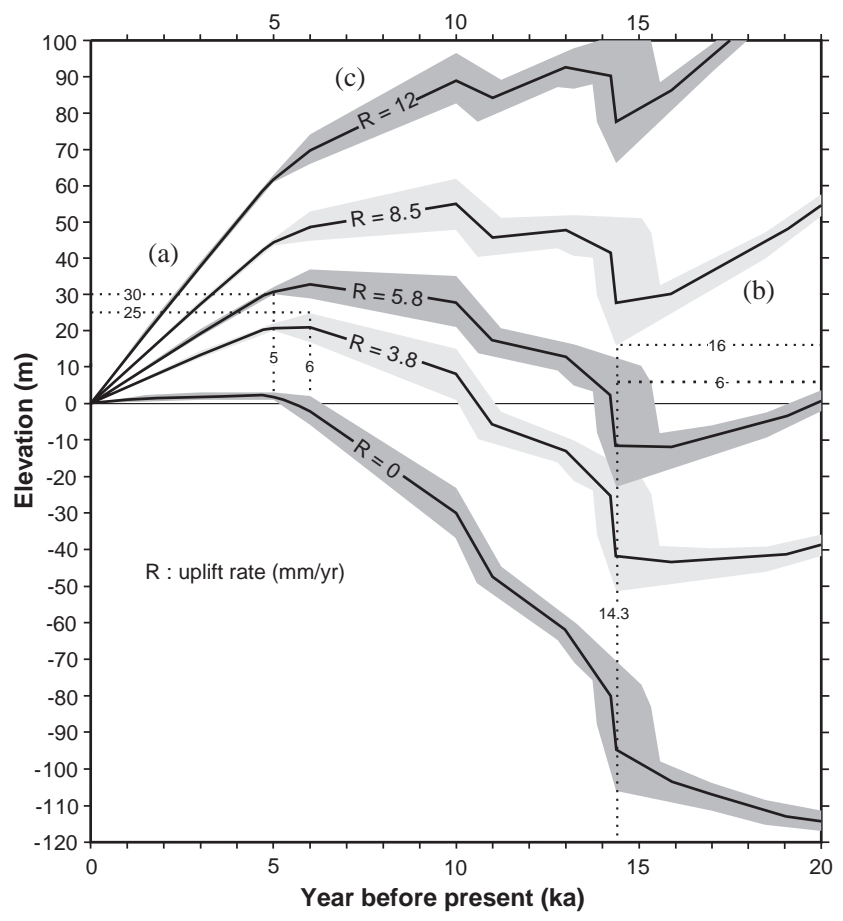

Fig. 11. Relative deglacial sea-level curves (solid line, average or most probable position) and uncertainties (shaded) under constant tectonic uplift rates. The assumed eustatic sea-level curve (and uncertainties) is given where uplift rate $(R)$ equals zero (see also Fig. 9). (a) The TH terrace north of Feng-pin has a shoreline angle $25-30 \mathrm{~m}$ in elevation. Assume that this shoreline angle was created when the relative sea level reached its highest stand, which corresponds to a maximum uplift rate of $5.8 \mathrm{~mm} / \mathrm{yr}$ (when the shoreline angle was created in $5 \mathrm{ka}$ ) and a minimum uplift rate of $3.8 \mathrm{~mm} / \mathrm{yr}$ (when the shoreline angle was created in $6 \mathrm{ka}$ ). (b) The lowest transgressive nearshore sediments exposed around San-chien-wu is $6 \mathrm{~m}$ in elevation. Assume that these sediments were deposited within a water depth of $10 \mathrm{~m}$, which corresponds to a maximum uplift rate of $8.5 \mathrm{~mm} / \mathrm{yr}$. (c) Once the uplift rate had been $12 \mathrm{~mm} / \mathrm{yr}$ or more, the relative sea level would have been falling for most of the time since the last glacial maximum.

movement of the relative sea level (and therefore tectonic uplift).

We also use the observed lowest transgressive marine sediments exposed near San-chien-wu (Fig. 5) to deduce the maximum uplift rate of the area. These sediments have a minimum elevation of lower than $6 \mathrm{~m}$. Assuming that they were deposited within a water depth of $10 \mathrm{~m}$, they yield a maximum uplift rate of $8.5 \mathrm{~mm} / \mathrm{yr}$. This is because once the uplift rate had exceeded this value the relative sea level during the late-glacial time would have reached the minimum (occurring 14-15 ka) at an elevation greater than $16 \mathrm{~m}$ (Fig. 11b). This maximum $8.5-\mathrm{mm} / \mathrm{yr}$ value further constrains the 6.4-9.8 and 7.7$9.1 \mathrm{~mm} / \mathrm{yr}$ uplift rates derived, respectively, from radiometric dates and the highest $(54 \mathrm{~m})$ beach sediments in the area (Fig. 10). Using the same approach, we obtain a maximum uplift rate of $8.1 \mathrm{~mm} / \mathrm{yr}$ for the seaward-most parts of all Type II terraces, assuming that the platforms underlying the terraces, now sloping underneath the sea level, had been eroded within a water depth of $10 \mathrm{~m}$ and when the relative late-glacial sea level reached the minimum. Note that most of the derived uplift rates are far greater than the rate of the rising late-glacial sea level before the meltwater pulse 1A. This meltwater event, therefore, should have started the marine transgression on most part of the coast. This suitably explains why the oldest marine sediments being dated, in the Tu-lan terrace, are $14-15 \mathrm{ka}$ in age (Pirazzoli et al., 1993).

\subsection{Summary}

Using both the dating and morphological evidence, we obtain a more complete Holocene uplift pattern along the coast (Fig. 10). The northernmost part of the coast from Ta-keng to Kan-tzu-shu-chua is uplifted at a rate of $3-4 \mathrm{~mm} / \mathrm{yr}$. The uplift rate is $3-4 \mathrm{~mm} / \mathrm{yr}$ around the Chi-chi Bay and decreases to $2-3 \mathrm{~mm} / \mathrm{yr}$ at Hsin-she. The uplift rate increases to $4-6 \mathrm{~mm} / \mathrm{yr}$ to the south, which corresponds to the rising of the TH terrace north of Tung-hsing. From here to Pa-hsien-tung, the uplift appears to be uniform or slightly increase in rate to the south, although this part of the coast (including the TH, FP, LY, SM, ST, STP and KC terraces), underlain mainly by volcanic rock, show great diversities in both elevation and morphology. The uplift rate increases rather rapidly to $8-9 \mathrm{~mm} / \mathrm{yr}$ around San-chien-wu and reaches a plateau between Chang-pin and Tan-man. From Tan-man to San-hsien-tai, the rate progressively decreases to $2-4 \mathrm{~mm} / \mathrm{yr}$, which corresponds to the overall lowering of the CA to SS terraces and agrees with the progressive southward migration of the Tu-we River north of Shih-yu-san (Fig. 6). In contrast, the Sanhsien River north of San-hsien-tai migrated to the north. This suggests that the minimum uplift occurs north of, or around, the mouth of the San-hsien River.

The uplift rate should increase south of San-hsien-tai, because the CK terrace around Cheng-kung is significantly higher than the SS terrace to the north. The uplift rate is $7-9 \mathrm{~mm} / \mathrm{yr}$ around the Pa-pien River. Farther south, the CK terrace significantly lowers north of Du-li (Fig. 7). This suggests a decrease of uplift rate, which is less than $3 \mathrm{~mm} / \mathrm{yr}$ south of Du-li. The uplift rate then increases to $7-8 \mathrm{~mm} / \mathrm{yr}$ near the Ma-wu-ku River. This rate probably increases to the south, as suggested by the higher shoreline angle of the CK terrace near Jin-jun than that exposed on the northern bank of the Ma-wu$\mathrm{ku}$ River, and by the progressive northward migration of the river (note that the Ma-wu-ku, San-hsien and Tuwe rivers are the only rivers in the coast that had significantly migrated laterally). The uplift maintains more than $6-7 \mathrm{~mm} / \mathrm{yr}$ to the south. It may be greater than $9.5 \mathrm{~mm} / \mathrm{yr}$ around Tu-lan, as suggested by archeological data showing that beach gravel $42-46 \mathrm{~m}$ in elevation could have been deposited later than $4 \mathrm{ka}$ (it is, 
Table 2

Uplift rates of the Hua-tung Coast derived from marine-terrace elevations

\begin{tabular}{|c|c|c|c|c|c|}
\hline \multirow[t]{2}{*}{ Location } & \multicolumn{3}{|l|}{ Elevation (m) } & \multirow{2}{*}{$\begin{array}{l}\text { Most likely time of } \\
\text { emergence (ka) }\end{array}$} & \multirow{2}{*}{$\begin{array}{l}\text { Average uplift } \\
\text { rate }(\mathrm{mm} / \mathrm{yr})\end{array}$} \\
\hline & Shoreline angle & $\begin{array}{l}\text { Highest marine } \\
\text { sediments }\end{array}$ & $\begin{array}{l}\text { Lowest transgressive } \\
\text { marine sediments or } \\
\text { bedrock platforms }\end{array}$ & & \\
\hline Ta-keng & & 20 & & $5-6$ & $3.0-3.8$ \\
\hline Chi-chi & $20-25$ & & & $5-6$ & $3.0-4.8$ \\
\hline S. of Hsin-she & $15-20^{\mathrm{a}}$ & & & $5-6$ & $2.2-3.8$ \\
\hline Tung-hsing & $25-30^{\mathrm{a}}$ & & & $\sim 6$ & $3.8-5.8$ \\
\hline Pa-hsien-tung & & 37 & & $6-10$ & $5.8-7.2$ \\
\hline San-chien-wu & & & $<6$ & & $<8.5$ \\
\hline San-chien-wu & & 54 & & $\sim 10$ & $7.7-9.1$ \\
\hline Chen-shan & & $>55$ & & $\sim 10$ & $>7.8$ \\
\hline Tan-man & & $>57$ & & $\sim 10$ & $>8.0$ \\
\hline Yung-fwu to Cheng-shan & & & $<0$ & & $<8.1$ \\
\hline Chung-an & & $>55$ & & $\sim 10$ & $>7.8$ \\
\hline Shih-yu-san & $40-45^{\mathrm{a}}$ & & & $6-10$ & $6.3-8.2$ \\
\hline N. of San-hsien-tai & $<20$ & & & $\sim 5$ & $<3.8$ \\
\hline Cheng-kung & $<50$ & & & $\sim 10$ & $<8.7$ \\
\hline Pa-pien River & $50-55$ & & & $\sim 10$ & $7.3-9.2$ \\
\hline Ma-wu-ku River & & 44 & & $6-10$ & $6.7-8.1$ \\
\hline Jin-jun & $45-50$ & & & $\sim 10$ & $6.8-8.7$ \\
\hline Chi-li River & & $>40$ & & & $>6.3$ \\
\hline Yang River & & $>40$ & & & $>6.3$ \\
\hline Tu-lan & & & $<0$ & & $<8.1$ \\
\hline Hsin River & & $>50$ & & $\sim 10$ & $>7.3$ \\
\hline Juin-jen & & $>55$ & & & $>7.8$ \\
\hline Yu-chang & & $<75$ & & & $<11.2$ \\
\hline
\end{tabular}

${ }^{\mathrm{a}}$ Extrapolated from outer parts of terraces that are $\leqslant 300 \mathrm{~m}$ in width.

however, unclear whether or not this beach deposit is of a great typhoon or tsunami origin). The uplift rate perhaps reaches the maximum of more than $10 \mathrm{~mm} / \mathrm{yr}$ south of Tu-lan (see discussion below). It decreases to 9$10 \mathrm{~mm} / \mathrm{yr}$ (or more) around Yu-chang and Fu-kang, and may continuously decrease to the south, as suggested by the apparent lowering of the FK terrace.

\section{Discussion: coastal features related to differential tectonic uplift}

\subsection{Origin of terrace risers curving inland}

Most of the terrace risers and their modern analogues along the coast are straight and parallel to the coast. Our observations on both the modern and paleoshorelines show that local erosion oblique to the regional trend of the shore is mainly associated with the development of fan-deltas or with their remnants. Exceptions, however, occur form north to south around (or near) Yung-fwu, Cheng-shan, Hsiao-kang, Sanhsien-tai, Cheng-kung, Du-li, Hsiao-ma and Lungchang; all of them cut into almost homogenous mudstone. Among them, only the terrace riser south of San-hsien-tai may be attributed to the existence of the
San-hsien-tai Cape (Fig. 7). Among others, the terrace risers around (or near) Yung-fwu (Fig. 6), Du-li (Fig. 7) and Lung-chang (Fig. 8) mark transitions between Type I and II terraces. The terrace riser north of Du-li also occurs with the apparent southward lowering of the CK terrace (Fig. 7). The terrace risers around Cheng-shan are bowl-shaped; the one around Hsiao-kang meanders (Fig. 6). The one near Cheng-kung corresponds with the southward narrowing of the $\mathrm{CK}$ terrace; the one around Hsiao-ma (the $\mathrm{HM}_{\mathrm{TR}}$ terrace riser) significantly trims the CK terrace (Fig. 7).

As suggested by the coincidence in location between the terrace riser north of Du-li and the inclination of the CK terrace (Fig. 7), the origin of these "atypical" terrace risers may be related to the differential tectonic uplift. We attribute this to the accommodation of coastal processes to the differential time of emergence of the terraces. Specifically, under the given rising deglacial sea level, terraces with greater uplift rates would start to emerge earlier than those with lower uplift rates (Lajoie, 1986). For example, the inferred 7-9-mm/yr uplift of the $\mathrm{CK}$ terrace north of Du-li requires that the terrace started to emerge during the onset of the Holocene. On the other hand, the CK terrace south of Du-li, with an uplift rate less than $3 \mathrm{~mm} / \mathrm{yr}$, was inundated by seawater until 5-6 ka. A possible scenario therefore suggests that 
one part of the coast was emerging while the rising seawater continuously flooded its adjacent part. Coastal erosion, if any, would create a sea cliff oblique to the land during this time.

The same scenario is likely to have occurred between Hsin-she and Tung-hsing where a slope striking normal to the shore and bounding the higher and lower $\mathrm{TH}$ terraces is developed (Fig. 4). This slope, indistinct due to the narrowness of the TH terrace, is in part erosional, as shown on the exposures. The TH terrace at Tunghsing, with an uplift rate of $4-6 \mathrm{~mm} / \mathrm{yr}$, should have emerged since $6 \mathrm{ka}$ or earlier, while the TH terrace to the north, with an uplift rate less than $4 \mathrm{~mm} / \mathrm{yr}$, was probably inundated by seawater until $5 \mathrm{ka}$.

We apply the model to the $\mathrm{HM}_{\mathrm{TR}}$ terrace riser around Hsiao-ma (Fig. 7). The uplift rate increases from Du-li to the Ma-wu-ku River, according to the dates (Fig. 10). This change in uplift rate should occur around or north of Hsiao-ma, because the CK terrace south from Hsiao$\mathrm{ma}$ is rather flat. The elevation change of the shoreline angle of the CK terrace north of Hsiao-ma is unclear due to the development of great alluvial fans (Fig. 7). We, however, propose that this differential uplift occurs in a rather narrower zone around Hsiao-ma, and is responsible for the inland curving of the $\mathrm{HM}_{\mathrm{TR}}$ terrace riser. Having the same condition, coastal erosion should have occurred between the SS terrace north of Sanhsien-tai and the higher CK terrace to the south (Fig. 6). The SS terrace does end to the south with an east-westtrending terrace riser (Fig. 6). This terrace riser is bounded by a minor volcanic ridge and may have been considered as a "typical" lithological boundary.

We recognize that the terrace risers transferring Type I to II terraces near Yung-fwu and Lung-chang, and those meandering around Cheng-shan and Hsiao-kang, are restricted to the seaward parts of major terraces. We suspect that the origin of these terrace risers may be related to local warping, similar to that observed on the CK terrace west and north of Cheng-kung (Fig. 7). The doming west of Cheng-kung may result in a minor terrace riser (or a structural axis?) trending along the southern edge of this dome (Fig. 7). North of Cheng-kung, the depression around the mouth of the Hsin-kang River did not accompany significant marine erosion (Fig. 7), which, however, may have been prevented by the sufficient supply of fluvial sediments from the river. Given the overall distinct coastal morphology and the proposed complex uplift pattern between San-hsien-tai and Cheng-kung (Fig. 7), it is possible that the origin of the bowl-shaped terrace riser south of San-hsien-tai is tectonic-related. Tectonics also should have controlled the drastic change of the width of the CK terrace and the development of the inlandcurving terrace riser near Cheng-kung, which will be discussed below.

\subsection{Origin of alternating Type I and II terraces}

The alternating Type I and II terraces present enigmatic features along the coast. In addition to those located around (or near) Yung-fwu, Du-li and Lungchang mentioned above, the changes from one type of the terrace to the other also occur near Cheng-kung, where the CK terrace changes its width, and at the mouth of the Ma-wu-ku River (Fig. 7). All of these places are neither close to headlands nor near submarine canyons that may affect wave regimes or along-shore sediment transport (Shen, 2001). In addition, except for the one near Cheng-kung, these coasts have straight modern shorelines and overall uniform (or gradually changing) widths of major terraces (Figs. 6-8).

We propose that the transition between the two types of terraces reflect warping of the coast. Specifically, the parts of the coast that develop Type II terraces would have been tilted seaward, but not for the coasts with Type I terraces. This interpretation is supported by the derived uplift rates. First, we obtain an uplift rate of 8 $9 \mathrm{~mm} / \mathrm{yr}$ (most likely, $8.0-8.6 \mathrm{~mm} / \mathrm{yr}$ ) around San-chienwu (Fig. 10). The uplift rate between Chang-pin and Tan-man must exceed this value, because the highest marine sediments (55-60 $\mathrm{m}$ in elevation) observed on the outer part of the $\mathrm{CP}$ terrace here are higher than the highest beach sediments ( $54 \mathrm{~m}$ in elevation) exposed on the inner edge of the terrace around San-chien-wu. We, however, obtained a maximum uplift rate of $8.1 \mathrm{~mm} / \mathrm{yr}$ for the outer parts of the Type II $\mathrm{CP}_{\mathrm{L}}$ terrace between Yung-fwu and Tan-man, given the seaward submergence of the mudstone platform underlying this terrace. Note that the landward edge of the CP terrace between Chang-pin and Tan-man is $75-80 \mathrm{~m}$ in elevation and is not covered by large alluvial fans. The shoreline angle of this terrace could be much higher than the highest marine sediments being exposed, and therefore corresponds to an uplift rate much greater than $8.1 \mathrm{~mm} / \mathrm{yr}$ (for example, a shoreline angle of $65 \mathrm{~m}$ in elevation would yield a minimum uplift rate of $8.8 \mathrm{~mm} / \mathrm{yr}$ ).

Second, we obtain a maximum uplift rate of $8.1 \mathrm{~mm} /$ $\mathrm{yr}$ for the Type II Tu-lan terrace. This rate is consistent with the rate of $5.9-6.5 \mathrm{~mm} / \mathrm{yr}$ based on the dates from the outer part of the terrace. This maximum $8.1-\mathrm{mm} / \mathrm{yr}$ rate, however, is far less than the minimum uplift rate of $9.5 \mathrm{~mm} / \mathrm{yr}$ suggested by the archeological data $1 \mathrm{~km}$ landward. This minimum uplift rate may not be representative of longer-term uplift. Still, we consider an uplift rate greater than $8.1 \mathrm{~mm} / \mathrm{yr}$ a reasonable value for the landward part of the Tu-lan terrace, given that the highest beach sediments exposed here, $50 \mathrm{~m}$ in elevation, are more than $1 \mathrm{~km}$ away from the landward edge of the terrace.

Our suggestion that Type I terraces would not have been tilted seaward is based on the fact that they are all 


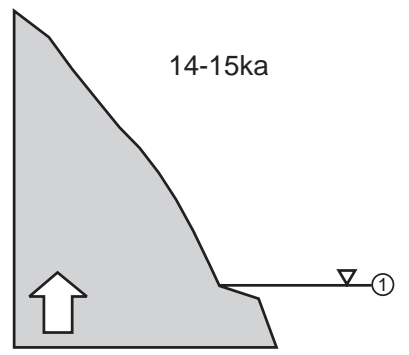

(a)

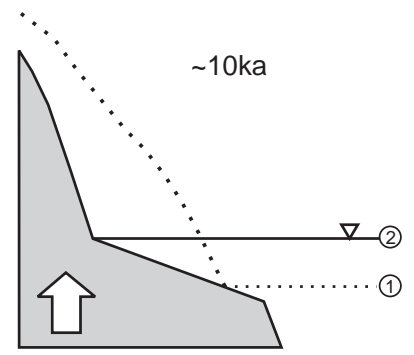

(b)

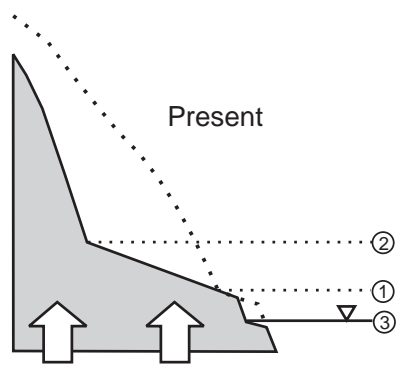

(c) (Type I terrace)

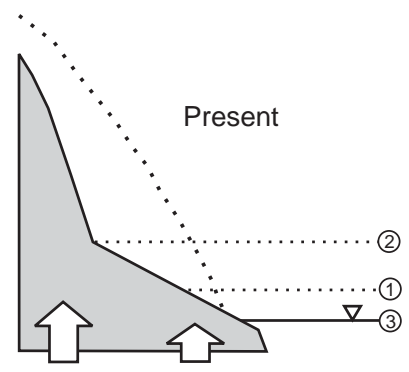

(d) (Type II terrace)

Fig. 12. Schematic cross sections showing the proposed contrast in origin of Type I and Type II terraces. (a) Topography of the coast during $14-15 \mathrm{ka}$ when the relative late-glacial sea level reached the minimum (see also Fig. 11). The uplift rate of the coast, at least the landward part, is assumed greater than $7-8 \mathrm{~mm} / \mathrm{yr}$. (b) Bedrock platform was eroded during the progressive submergence of the land until $10 \mathrm{ka}$. (c) Relative sea-level fall has exposed the topography preexisting by $14-15 \mathrm{ka}$, where the coast is uplifted uniformly at rates greater than $7-8 \mathrm{~mm} / \mathrm{yr}$. Steep submarine slope then caused significant coastal erosion (resulting in Type I terraces). (d) Relative sea-level fall has yet to expose the topography pre-existing by $14-15 \mathrm{ka}$, where the seaward part of the coast is uplifted less than $7-8 \mathrm{~mm} / \mathrm{yr}$ (resulting in Type II terraces).

truncated by prominent sea cliffs or terrace risers. Note that whereas the coast was uplifted at a rate of greater than $7-8 \mathrm{~mm} / \mathrm{yr}$, which is likely to be the case for most Type I (and landward parts of Type II) terraces, the bedrock platform created since the relative late-glacial sea-level minimum (14-15 ka) would have entirely emerged (Figs. 11 and 12). In other words, the more recent falling sea level would have exposed the original slopes of the coast that are much steeper than the platforms (Fig. 12). These steep coasts would not favor along-shore sediment transport and accumulation. This suitably explains why the coasts bounding Type I terraces have been erosive, and are undergoing very rapid retreat.

Our model can be readily linked to the suspected warping near Yung-fwu and Lung-chang (Figs. 6 and 8). This type of warping also may have occurred near Cheng-kung and at the mouth of the Ma-wu-ku River (Fig. 7). In both areas, the uplift rates increase to the south, which could further enhance the development of Type I terraces in the south.

\subsection{Reason for lack of marine terraces south of Tu-lan}

A gap of major terraces exists between the CK terrace (around Tu-lan) and the FK terrace (around Yu-chang) (Figs. 3 and 8). This part of the coast is underlain by mudstone, but unlike the coast bounding Type I terraces, is not erosive. The CK and FK terraces appear to decrease in width but increase in height toward this part of the coast. This implies that the coast could be uplifted even more actively than the two terraces, which have uplift rates of $9-10 \mathrm{~mm} / \mathrm{yr}$ (Fig. 10). We believe that this extremely rapid uplift is the reason why the coast did not develop distinct marine terraces, because whereas the uplift rate exceeded, say, $12 \mathrm{~mm} / \mathrm{yr}$, the eustatic sea level would not have caught up with the uplift for most of the time since the last glacial maximum (Fig. 11c). In this case, even though the relative sea level had risen, for example, during the meltwater pulse $1 \mathrm{~A}$ and $1 \mathrm{~B}$, it was brief and could not have created bedrock platforms wide enough to be preserved during the subsequent, prolonged relative sealevel fall.

\section{Implication: uplift and activity of bedrock structures}

Most of the Hua-tung coast is uplifted very rapidly during the Holocene. We, however, do not observe any terraces that show offsets by faulting (except for the minor one exposed near Feng-pin). We define tectonic boundaries where the uplift changes in rate or style (from uniform to seaward tilting) rather abruptly along the coast (Fig. 13). The areas south of Kan-tzu-shu-chua and north of Chi-chi may also be uplift boundaries (Liew et al., 1990), given the poor development of marine terraces between the two places (Figs. 3 and 13). All of these boundaries are transitional and could cover lengths more than several hundreds of meters along the coast. Except for the one around Hsiao-ma, none of these uplift boundaries can be connected to known bedrock structures, including the Chi-chi "fault" of Hsu (1956) (Fig. 13). Nonetheless, the boundary around Hsiao-ma may match in location with the Ta-ma fault (or the Tu-luan-shan "fault" of Hsu). The apparently more active uplift of the CK terrace south of Hsiao-ma agrees with the westward thrust-movement of the fault. Comparable uplift, however, is not observed around Jinjun, where the Ta-ma fault crosses the CK terrace again. Given this, the inland-extending Tu-luan-shan "fault" (lineament) may be a better uplift boundary than the Ta-ma fault (cf. Lin, 1994).

The Chi-mei fault separating the TH and FP terraces on either side of the Feng-pin River (Fig. 4) was considered to be the most important active fault of the region. The TH and FP terraces do have different elevations. However, the $\mathrm{TH}$ terrace is underlain by 


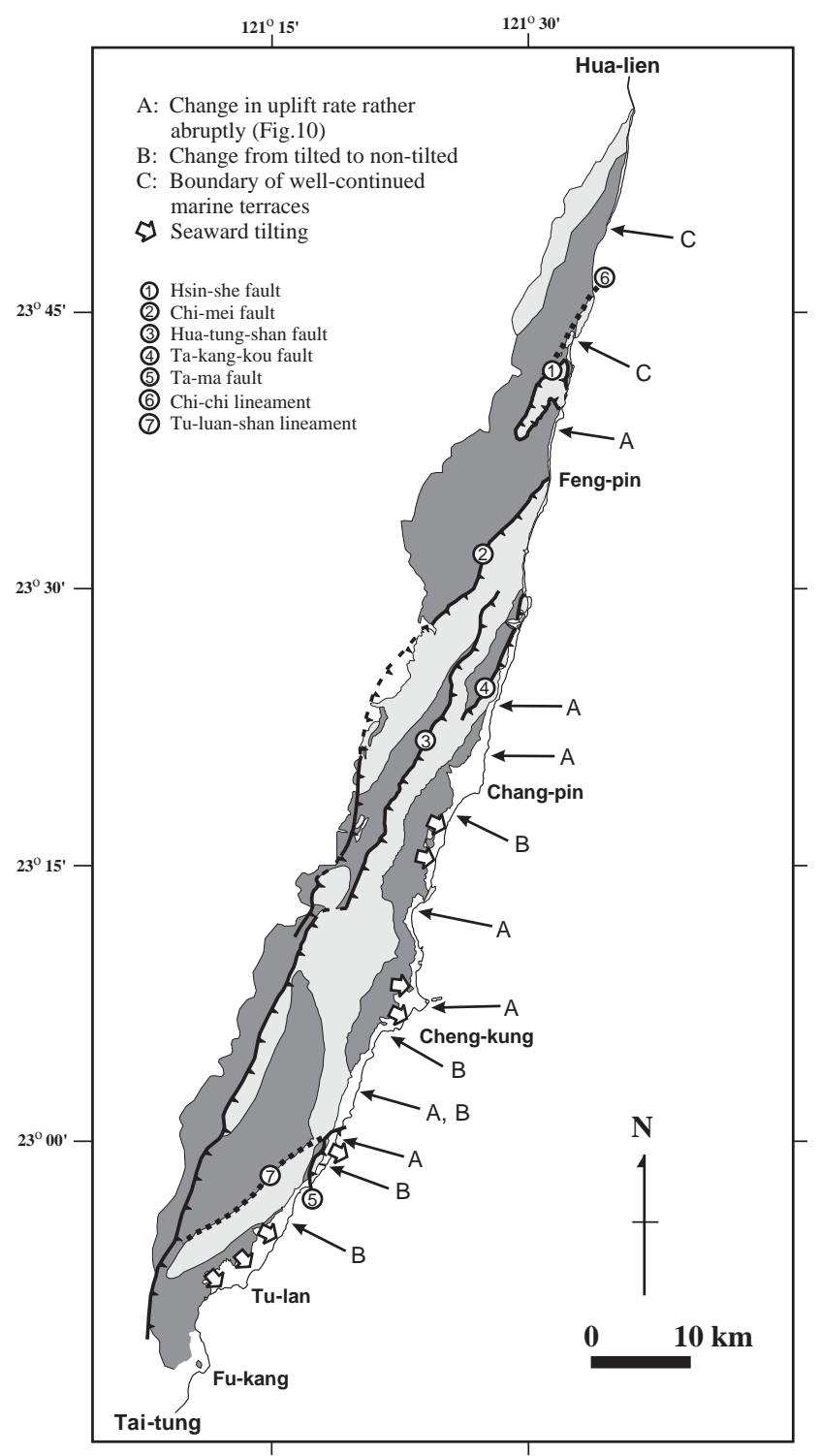

Fig. 13. Summary of inferred Holocene uplift boundaries in this study. Legends as in Fig. 2. Note the apparent irrelevance of these boundaries to bedrock structures.

mudstone and the FP terrace by volcanic rock; their difference in elevations cannot be used as a solid evidence of the movement of the fault. In fact, the uplift rates derived from the two terraces (and farther south crossing the Ta-kang-kou fault) are comparable (Fig. 10). Although a Holocene fault is exposed on the southern bank of the Feng-pin River, it is indistinct on the aerial photographs and has a vertical offset of only $1-2 \mathrm{~m}$. This fault is unlikely to be a major tectonic feature. In addition, the Chi-mei fault does not displace river-terrace sequences in the Feng-pin River. It is therefore arguable whether the Chi-mei fault has actively moved during the Holocene.

We recognize that our observations only cover the time span of Holocene and are restricted to the coastal area. Even so, our observations do not support the notion by Vita-Finzi and Lin (1998), who treated the uplift of the coast as movements of distinct tracts bounded by imbricate reverse faults. Lin (1994) suggested these tracts had progressively emerged and been accreted, as the collision migrated to the southeast. Note, however, that parts of these tract-bounded "faults" have been considered non-existent (Lo et al., 1993; Chen and Wang, 1997). In addition, the major faults (except for the Hsin-she fault) and their bounding volcanic rocks are all cut at high angles by major rivers, from north to south, the Hsiu-ku-luan, Shui-mu-tin, and Ma-wu-ku rivers (Fig. 2). The Fan-shu-liao River in the north also traverses volcanic rock in its downstreammost reach (Fig. 2). As pointed out by Lundberg and Dorsey (1990), given the rapid uplift and great contrast in resistance to erosion between the volcanic and sedimentary rocks, any headward erosion or capture of drainage is likely to have proceeded along the structural strikes. In other words, if the Coastal Range had emerged part-by-part separated by major thrust faults, there should have been axial rivers draining parallel to the faults, like those flowing in the Longitudinal Valley. Instead, the transverse nature of all these rivers implies that they are either antecedent or consequent types (Lundberg and Dorsey, 1990); both require that the Coastal Range had emerged as a more or less single unit.

In sum, we see no evidence that the major faults inside the Coastal Range, having moved since middle to late Pleistocene, had played an important role during the emergence of the range. Neither do these faults show significant activities during the Holocene, according to our data. Our observation that most of the Holocene uplift boundaries are irrelevant to bedrock structures further suggests a fundamental change in style, and perhaps also mechanics, of the uplift in the past. Our observed seaward tilting of the coast agrees with the geodetic data in that the uplift (and deformation) is widely distributed inside the range, rather than concentrated along certain discrete zones (Chen, 1984). Given that the derived uplift rates in the coastal zone are commonly $5-10 \mathrm{~mm} / \mathrm{yr}$ (Fig. 10), the uplift rates inside the range would be greater than these values and comparable with the long-term minimums of $7.5 \mathrm{~mm} / \mathrm{yr}$ (Lundberg and Dorsey, 1990), or $12 \mathrm{~mm} / \mathrm{yr}$ (Chen et al., 1991) for bedrock formations. From this point of view, our obtained uplift rates and pattern in general may be considered representative over a time period much longer than the Holocene.

\section{Conclusions}

Using both dating and morphological evidence, we obtained an uplift pattern along the $140-\mathrm{km}-$ long 
Hua-tung coast over the Holocene time span. With a boundary roughly located between Pa-hsien-tung and Chang-pin, the northern part of the coast appears to be uplifted less actively than the southern part of the coast. The northern-most $30 \mathrm{~km}$ of the coast from the Hua-lien River to Hsin-she has uplift rates less than $4 \mathrm{~mm} / \mathrm{yr}$. The following $30-\mathrm{km}$-long coast to Pa-hsien-tung is uplifted more or less uniformly at rates of $4-7 \mathrm{~mm} / \mathrm{yr}$. To the south, the remaining $80-\mathrm{km}$-long coast is generally uplifted at $7-10 \mathrm{~mm} / \mathrm{yr}$, with local troughs (about $5 \mathrm{~km}$ in length and $<4 \mathrm{~mm} / \mathrm{yr}$ in uplift rate) occurring around the mouth of the San-hsien River and around Du-li. The crest of the uplift, with rates greater than $10 \mathrm{~mm} / \mathrm{yr}$, is probably located between Tu-lan and Fu-kang in the southernmost part of the coast. In addition to these variations in uplift along the coast, seaward tilting is suggested in many places in the middle and southern parts of the coast that develop wide $(>700 \mathrm{~m})$ mudstone platforms sloping from elevations more than $40 \mathrm{~m}$ to the sea level. Local warping also is suggested in some places. Those with east-west trending axes near Cheng-kung mark the area as a complex tectonic boundary.

Except for a minor one near Feng-pin, we do not detect any faults that offset terraces. We define tectonic boundaries where the uplift changes in rate or style (from uniform to seaward tilting) rather abruptly along the coast. All of these boundaries are transitional and could cover lengths more than several hundreds of meters along the coast. Among them, only the one around Hsiao-ma may be connected to the bedrock Tama reverse fault (or the Tu-luan-shan lineament). Given this, the activity and the role of the known faults upon the uplift of the Coastal Range during the Holocene are arguable. Instead, a change in style, and perhaps also mechanics, of the uplift may be suggested. This change may have occurred long before or during the emergence of the range, as suggested by the prevailing antecedent or consequent types of drainages in the range.

\section{Acknowledgements}

This study is sponsored by the National Science Council, Taiwan. We thank Dr. York Ota of Yokohama National University, Japan, and Dr. Wen-Shan Chen of National Taiwan University, for their helpful discussions and suggestions. We also greatly appreciate Miss Yu-Nong Lin, Miss Yang-Hue Hsu, Miss ChioYun Lien, Mr. Tsung-Mao Lee and Mr. Bing-Cheng Chen of National Taiwan University for their kindly assistance in the field. We finally thank Miss Tsun-Yeng Chou and Miss Su-Jane Kang who performed the radiocarbon dating in the laboratory of National Taiwan University.

\section{References}

Biq, C.C., 1972. Transcurrent buckling, transform faulting and transpression: their relevance in eastern Taiwan kinematics. Petroleum Geology of Taiwan 10, 1-10.

Biq, C.C., 1973. Kinematic pattern of Taiwan as an example of actual continent-arc collision. In: Report of the Seminar on Seismology US-ROC Cooperative Science Program, Republic of China, Taipei, pp. 21-26.

Bradley, W.C., 1958. Submarine abrasion and wave-cut platforms. Geological Society of America Bulletin 69, 967-974.

Bradley, W.C., Griggs, G.B., 1976. Form, genesis and deformation of Central California wave-cut platforms. Geological Society of America Bulletin 87, 433-449.

Burbank, D.W., Leland, J., Fielding, E., Anderson, R.S., Brozovic, N., Reid, M.R., Duncan, C., 1996. Bedrock incision, rock uplift and threshold hillslopes in the northwestern Himalayas. Nature 379, 505-510.

Chen, H.F., 1984. Crustal uplift and subsidence in Taiwan: an account based upon retriangulation results. Special Publication of the Central Geological Survey (Taiwan) 3, 129-140 (in Chinese).

Chen, W.S., 1988. Evolution of the sedimentary basins of the Coastal Range, eastern Taiwan, and its tectonic implications. Unpublished $\mathrm{Ph} . \mathrm{D}$. Thesis, Institute of Geology, National Taiwan University, Taipei, pp. 304 (in Chinese)

Chen,, Y.G., Liu, T.K., 1996. Sea level changes in the last several thousand years, Penghu Islands, Taiwan Strait. Quaternary Research 45, 254-262.

Chen, Y.G., Liu, T.K., 2000. Holocene uplift and subsidence along an active tectonic margin, southwestern Taiwan. Quaternary Science Reviews 19, 923-930.

Chen, W.S., Wang, Y., 1997. Geological Map of Fengpin. Central Geological Survey Taiwan, Scale 1:50000.

Chen, W.S., Huang, M.T., Liu, T.K., 1991. Neotectonic significance of the Chimei fault in the Coastal Range, eastern Taiwan. Proceedings of the Geological Society of China 34, 43-56.

Fairbanks, R.G., 1989. A 17000-year glacio-eustatic sea level record: influence of glacial melting rates on the Younger Dryas event and deep-ocean circulation. Nature 342, 637-642.

Hanebuth, T., Stattegger, K., Grootes, P.M., 2000. Rapid flooding of the Sunda Shelf: a late-glacial sea-level record. Science 288, 1033-1035.

Ho, C.S., 1986. A synthesis of the geologic evolution of Taiwan. Tectonophysics $125,1-16$.

Hsieh, M.L., 1990. Study of Late Quaternary deposits, marine terraces and neotectonism of the coastal area between Hualien and Taitung. Unpublished M.S. Thesis, Institute of Geology, National Taiwan University, Taipei, 168pp. (in Chinese).

Hsieh, M.L., Lai, T.H., Liew, P.M., 1994. Holocene climatic river terraces in an active tectonic-uplifting area, middle part of the Coastal Range, eastern Taiwan. Journal of the Geological Society of China 37, 97-114.

Hsieh, M.L., Liew, P.M., Ota, Y., 2001. The dynamic Hualien-Taitung coast, eastern Taiwan. Field guide for the 2001 International Meeting on both Sea-level changes and coastal evolution (INQUA) and Neotectonics (INQUA), MTER, Taiwan, 53pp.

Hsu, T.L., 1954. On the geomorphic features and the recent uplifting movement of the Coastal Range, eastern Taiwan. Bulletin of the Geological Survey of Taiwan 7, 51-57.

Hsu, T.L., 1956. Geology of the Coastal Range, eastern Taiwan. Bulletin of the Geological Survey of Taiwan 8, 39-63.

Hsu, M.Y., 1988. A geomorphological study of marine terraces in Taiwan. Unpublished Ph.D. Thesis, Institute of Earth Science, Chinese Culture University, Taipei, 163pp. (in Chinese).

Hsu, Yu.C., Chou, M.C., Hsu, Yi.C., Lin, S.Y., Lu, S.C., 1973. National Taiwan University radiocarbon measurements II. Radiocarbon $15,345-349$. 
Hsu, M.Y., Kao, C.J., Kao, P.F., Jeng, S.L., 1998. A study of coastal retreat along Huatung Coast, Hualien to Changpin section. Bulletin of the Geographical Society of China 26, 73-98 (in Chinese).

Hsu, M.Y., Kao, C.J., Kao, P.F., Jeng, S.L., 1999. A study of coastal retreat along Huatung Coast, Changpin to Taitung section. Bulletin of the Geographical Society of China 27, 83-109 (in Chinese).

Huang, S.C., 1991. Some issues about the prehistoric cultures of East Coast. Field Archeology of Taiwan 2, 1-30 (in Chinese).

Huang, C.Y., Yuan, P.B., Teng, L.S., 1988. Paleontology of the Kangkou Limestone in the middle Coastal Range, eastern Taiwan. Acta Geologica Taiwanica 26, 133-160.

Hull, A.G., 1987. A late Holocene marine terrace on the Kidnappers coast, North Island, New Zealand. Quaternary Research 28, 183-195.

Lai, C.K., 1987. Study of marine terraces from Chengkung to Fengpin, Coastal Range, eastern Taiwan. Unpublished M.S. thesis, Institute of Geography, National Taiwan University, Taipei, 101pp. (in Chinese).

Lajoie, K.R., 1986. Coastal tectonics. In: Wallace, R.E. (Ed.), Active Tectonics. National Academic Press, Washington, DC, pp. 95-124.

Lee, T.Q., Kissel, C., Barrier, E., Laj, C., Chi, W.R., 1991. Paleomagnetic evidence for a diachronous clockwise rotation of the Coastal Range, eastern Taiwan. Earth and Planetary Science Letters 104, 245-257.

Liew, P.M., Hsieh, M.L., Lai, C.K., 1990. Tectonic significance of Holocene marine terraces in the Coastal Range, eastern Taiwan. Tectonophysics 183, 121-127.

Liew, P.M., Pirazzoli, P.A., Hsieh, M.L., Arnold, M., Barusseau, J.P., Fontugne, M., 1993. Holocene tectonic uplift deduced from elevated shorelines, eastern Coastal Range of Taiwan. Tectonophysics $222,55-68$.

Lin, J.F., 1989. Studies of ${ }^{234} \mathrm{U} /{ }^{230} \mathrm{Th}$ dating on the Holocene corals of eastern and southern Taiwan. Unpublished M.S. Thesis, Institute of Geology, National Taiwan University, Taipei, 112pp. (in Chinese).

Lin, J.C., 1994. An evolutionary model for the Coastal Range, eastern Taiwan. In: Kirkby, M.J. (Ed.), Process Models and Theoretical Geomorphology. Wiley, West Sussex, England, pp. 97-112.

Liu, C.C., Yu, S.B., 1990. Vertical crustal movements in eastern Taiwan and their tectonic implications. Tectonophysics 183, $111-120$.

Liu, Y.S., Yen, T.Y., 2000. Researches of Pre-historical Relics in the Taitung County - the eastern Coastal Range and the Green Island. Institute of History and Language, Academic Sinica, pp. 177 (in Chinese).

Lo, H.J., Song, S.R., Chen, W.S., 1993. Geological Map of Chengkung. Central Geological Survey (Taiwan), Scale 1:50000.

Lundberg, N., Dorsey, R.J., 1990. Rapid Quaternary emergence, uplift, and denudation of the Coastal Range, eastern Taiwan. Geology 18, 638-641.
Ota, Y., Berryman, K.R., Hull, A.G., Miyauchi, T., Iso, N., 1988. Holocene transgressive deposits in eastern North Island, New Zealand. Palaeogeography, Palaeoclimatology, Palaeoecology 68, 135-151.

Peng, Z., Li, Y., Wu, F., 1977. Tectonic uplift of Taiwan Island since the early Holocene. Memoirs of Geological Society of China 2, 57-69.

Pirazzoli, P.A., Arnold, M., Giresse, P., Hsieh, M.L., Liew, P.M., 1993. Marine deposits of late glacial times exposed by tectonic uplift on the east coast of Taiwan. Marine Geology 110, 1-6.

Shen, S.M., 2000. Geomorphological and tectonic controls on coastal erosion, Huatung Coast, Eastern Taiwan. Unpublished Ph.D. Thesis, University of California at Los Angeles, 284pp.

Shen, S.M., 2001. Preliminary analysis on net longshore-current direction and delineation of littoral cells along the Huatung coast, eastern Taiwan. In: The Symposium of the Fifth Taiwan Geographic Conference, Taipei, pp. 216-235.

Shih, T.T., Teng, K.H., 1977. The marine terraces in the HualienTaitung coast, eastern Taiwan. Vol. 3, Geographical Education, National Normal University, Taipei, pp. 12-19 (in Chinese).

Song, S.R., Lo, H.J., 1988. Andesites and related rocks of the Coastal Range, eastern Taiwan. In: Symposium on the Arc-continent Collision and Orogenic Sedimentation in Eastern Taiwan and Ancient Analogs, Field Guidebook, Taipei, pp. 5.1-5.25.

Song, S.R., Lo, H.J., Chen, W.S., 1994. Origin of clastic dikes in the Coastal Range, eastern Taiwan, with implications for sedimentary processes during the arc-continent collision. Journal of the Geological Society of China 37, 407-424.

Stuiver, M., Reimer, P.J., 1993. Extended ${ }^{14} \mathrm{C}$ data base and revised CALIB3.0 ${ }^{14} \mathrm{C}$ age calibration program. Radiocarbon $35,215-230$.

Sung, W.H., 1969. Changpinian: a newly discovered Preceramic culture from the agglomerate caves on the east coast of Taiwan (preliminary report). Newsletter of Chinese Ethnology 9, 1-27 (in Chinese).

Teng, L.S., 1990. Geotectonic evolution of the late Cenozoic arccontinent collision in Taiwan. Tectonophysics 183, 57-76.

Teng, L.S., Lo, H.J., 1985. Sedimentary sequences in the island arc settings of the Coastal Range, eastern Taiwan. Acta Geologica Taiwanica 23, 77-98.

Vita-Finzi, C., Lin, J.C., 1998. Serial reverse and strike slip on imbricate faults: the Coastal Range of east Taiwan. Geology 26, 279-281.

Wang, U., Yang, C.N., Chen, W.S., 1992. Geological Map of Yuli. Central Geological Survey (Taiwan), Scale 1:50000.

Yamaguchi, M., Ota, Y., 2001. Tectonic and paleoseismological significance of Holocene marine terraces on the east coast of Coastal Range, Taiwan (Hualien to Taitung). In: Abstracts, First International Meeting on both Sea-level Change and Coastal Evolution \& Neotectonics (INQUA), Taipei, pp. 20-22.

Yen, T.P., 1968. Volcanic geology of the Coastal Range, eastern Taiwan. Proceedings of the Geological Society of China 11, 74-88.

Yu, S.B., Chen, H.Y., Kuo, L.C., 1997. Velocity field of GPS stations in the Taiwan area. Tectonophysics 274, 41-59. 